OPEN ACCESS

Edited by:

Martina Schmidt,

University of Groningen, Netherlands

Reviewed by:

Laurent Counillon,

University of Nice Sophia Antipolis,

France

Igor Pottosin,

University of Colima, Mexico

${ }^{*}$ Correspondence:

Michael Kittl

michael.kitt@@mu.ac.at

Specialty section:

This article was submitted to

Cell Death and Survival,

a section of the journal

Frontiers in Cell and Developmental

Biology

Received: 28 October 2021

Accepted: 31 December 2021

Published: 02 February 2022

Citation:

Kittl M, Winklmayr M,

Preishuber-Pflügl J, Strobl V, Gaisberger $M$, Ritter $M$ and Jakab $M$ (2022) Low pH Attenuates Apoptosis by Suppressing the Volume-Sensitive Outwardly Rectifying (VSOR) Chloride

Current in Chondrocytes. Front. Cell Dev. Biol. 9:804105. doi: 10.3389/fcell.2021.804105

\section{Low pH Attenuates Apoptosis by Suppressing the Volume-Sensitive Outwardly Rectifying (VSOR) Chloride Current in Chondrocytes}

\author{
Michael Kittl ${ }^{1,2 *}$, Martina Winklmayr ${ }^{1,2}$, Julia Preishuber-Pflügl $I^{1,3}$, Victoria Strobl ${ }^{1,3}$, \\ Martin Gaisberger ${ }^{1,2,3}$, Markus Ritter ${ }^{1,2,3,4}$ and Martin Jakab ${ }^{1,2}$ \\ ${ }^{1}$ Center for Physiology, Pathophysiology and Biophysics, Institute for Physiology and Pathophysiology - Salzburg, Paracelsus \\ Medical University, Salzburg, Austria, ${ }^{2}$ Ludwig Boltzmann Institute for Arthritis and Rehabilitation, Salzburg, Austria, ${ }^{3}$ Gastein \\ Research Institute, Paracelsus Medical University, Salzburg, Austria, ${ }^{4}$ Center for Physiology, Pathophysiology and Biophysics, \\ Institute for Physiology, Pathophysiology and Biophysics - Nuremberg, Paracelsus Medical University, Nuremberg, Germany
}

In a variety of physiological and pathophysiological conditions, cells are exposed to acidic environments. Severe synovial fluid acidification also occurs in a progressive state of osteoarthritis (OA) affecting articular chondrocytes. In prior studies extracellular acidification has been shown to protect cells from apoptosis but the underlying mechanisms remain elusive. In the present study, we demonstrate that the inhibition of $\mathrm{Cl}^{-}$currents plays a significant role in the antiapoptotic effect of acidification in human articular chondrocytes. Drug-induced apoptosis was analyzed after exposure to staurosporine by caspase $3 / 7$ activity and by annexin-V/7-actinomycin $D$ (7-AAD) staining, followed by flow cytometry. Cell viability was assessed by resazurin, CellTiterGlo and CellTiter-Fluor assays. $\mathrm{Cl}^{-}$currents and the mean cell volume were determined using the whole cell patch clamp technique and the Coulter method, respectively. The results reveal that in C28/I2 cells extracellular acidification decreases caspase 3/7 activity, enhances cell viability following staurosporine treatment and gradually deactivates the volume-sensitive outwardly rectifying (VSOR) $\mathrm{Cl}^{-}$current. Furthermore, the regulatory volume decrease (RVD) as well as the apoptotic volume decrease (ADV), which represents an early event during apoptosis, were absent under acidic conditions after hypotonicityinduced cell swelling and staurosporine-induced apoptosis, respectively. Like acidosis, the VSOR $\mathrm{Cl}^{-}$current inhibitor DIDS rescued chondrocytes from apoptotic cell death and suppressed AVD after induction of apoptosis with staurosporine. Similar to acidosis and DIDS, the VSOR channel blockers NPPB, niflumic acid (NFA) and DCPIB attenuated the staurosporine-induced AVD. NPPB and NFA also suppressed staurosporine-induced caspase 3/7 activation, while DCPIB and Tamoxifen showed cytotoxic effects per se. From these data, we conclude that the deactivation of $\mathrm{VSOR} \mathrm{Cl}^{-}$currents impairs cell volume regulation under acidic conditions, which is likely to play an important role in the survivability of human articular chondrocytes.

Keywords: apoptosis, AVD, caspase, chloride, chondrocytes, pH, viability, volume regulation 


\section{INTRODUCTION}

The volume-sensitive outwardly rectifying (VSOR) $\mathrm{Cl}^{-}$channel is ubiquitously expressed in almost all vertebrate cells and is a key player in cell volume regulatory processes. The channel, which opens upon osmotic cell swelling, contributes to regulatory volume decrease (RVD) by extruding anions and organic osmolytes (Jentsch, 2016; Pedersen et al., 2016; Chen et al., 2019; Okada et al., 2020). In addition to its volume regulatory role in various physiological functions like migration, phagocytosis, and proliferation (Jakab and Ritter, 2006; Schwab et al., 2012; Harl et al., 2013; Wanitchakool et al., 2016; Kittl et al., 2019b), VSOR anion channels are also involved in apoptotic cell death (Okada and Maeno, 2001; Okada et al., 2006; Kondratskyi et al., 2015; Pedersen et al., 2016; Okada et al., 2020).

Apoptosis is characterized by a normotonic cell shrinkage that occurs at an early phase followed by caspase activation, chromatin condensation, DNA fragmentation and plasma membrane blebbing (Elmore, 2007). This initial normotonic cell shrinkage, referred to as apoptotic volume decrease (AVD), is a major hallmark of apoptosis and is necessary to induce apoptotic cell death (Maeno et al., 2000; Okada and Maeno, 2001; Bortner and Cidlowski, 2004; Ernest et al., 2008; Poulsen et al., 2010; Kondratskyi et al., 2015; Okada et al., 2020). Several authors concluded that the activation of VSOR channels is involved in AVD by showing that on the one hand inducers of apoptosis like staurosporine, doxorubicin, FAS ligand, TNFa, or $\mathrm{H}_{2} \mathrm{O}_{2}$ activate VSOR channels under normotonic conditions (D'anglemont De Tassigny et al., 2004; Porcelli et al., 2004; Shimizu et al., 2004; Jiao et al., 2006; Okada et al., 2020) and on the other hand pharmacological inhibition of VSOR channels impairs apoptosis by preventing AVD (Maeno et al., 2000; Okada et al., 2006). Not only pharmacological inhibition but also LRRC8 knock-out cells, which were lacking either the LRRC8A isoform or all LRRC8 isoforms, displayed reduced caspase-3 activity after exposure to staurosporine or cisplatin (Planells-Cases et al., 2015). Moreover, a facilitated RVD response under hypotonic conditions in apoptotic cells indicates, that both mechanisms-AVD and RVD-are coupled and require the activation of VSOR channels to induce normotonic or hypotonic cell shrinkage, respectively. Additionally, the assumption of a common mechanism underlying both AVD and RVD is supported by the finding that AVD induction as well as RVD facilitation are prevented by the application of the same $\mathrm{Cl}^{-}$channel blockers (Maeno et al., 2000; Okada and Maeno, 2001; Okada et al., 2001; Okada et al., 2020). While shrunken cells under physiological conditions undergo a regulatory volume increase (RVI) by gain of solutes and water (Lang et al., 1998; Hoffmann et al., 2009), apoptotic cells remain shrunken without compensating the cell volume (Maeno et al., 2006). This indicates that cell volume regulatory processes, like RVI and RVD, which "normally" protect cells from excessive cell shrinkage or cell swelling, respectively, operate differently in apoptotic cells. In this regard, RVD is supposed to be activated under normotonic conditions to induce apoptosis (AVD) and RVI might be overridden to preserve cell shrinkage during apoptosis (Bortner and Cidlowski, 1996; Maeno et al., 2000). In recent studies we could show that lowering the extracellular $\mathrm{pH}$ to $\leq 5.0$ leads to a deactivation of the VSOR current and to an impaired volume regulation in microglial cells and chondrocytes (Kittl et al., 2019a; Kittl et al., 2020). Acidity is also reported to influence apoptosis, but literature data are contradictory. While several studies have demonstrated that a low extracellular $\mathrm{pH}$ favors the induction of apoptosis (Ding et al., 2000; Thatte et al., 2004; Kumar et al., 2007), in other studies acidification has been found to inhibit apoptosis. A protective effect of acidosis has been observed in different cell types including endothelial cells (D'Arcangelo et al., 2000; D’Arcangelo et al., 2002; Terminella et al., 2002; Kumar et al., 2008), liver cells (Currin et al., 1991), lymphoblastic cells (Bohloli et al., 2016), neurons (Xu et al., 1998), colon adenocarcinoma cells (Sharma et al., 2005) and osteoclasts (Pereverzev et al., 2008). The mechanisms underlying the protective effect of acidosis against apoptosis are still unclear.

Our present study provides more insight into this topic by investigating the effect of acidosis on apoptosis in human articular chondrocytes and testing whether $\mathrm{VSOR} \mathrm{Cl}^{-}$channels play a role in the capability of acidosis to inhibit apoptosis.

\section{MATERIALS AND METHODS}

\section{Salts, Chemicals, Drugs}

All salts and chemicals were p.a. grade. DCPIB (4-[(2-butyl-6,7dichloro-2-cyclopentyl-1-oxo-3H-inden-5-yl)oxy]butanoic acid) was purchased from Tocris (Abingdon, United Kingdom), DIDS (4,4'-diisothiocyano-2,2'-stilbenedisulfonic acid), niflumic acid (NFA; 2-[3-(trifluoromethyl)anilino]pyridine-3-carboxylic acid), NPPB (5-nitro-2-(3-phenylpropylamino)benzoic acid), tamoxifen (2-[4-[(Z)-1,2-diphenylbut-1-enyl]phenoxy]-N,Ndimethylethanamine) and staurosporine were purchased from SigmaAldrich-Merck (Darmstadt, Germany). Stock solutions of DCPIB $(100 \mathrm{mM})$ and Tamoxifen $(40 \mathrm{mM})$ were prepared in ethanol. DIDS, NFA, NPPB and staurosporine were dissolved in dimethyl sulfoxide (DMSO) to give stock solutions of $100 \mathrm{mM}$, $100 \mathrm{mM}, 100 \mathrm{mM}$ and $1 \mathrm{mM}$, respectively. The stocks were stored in aliquots at $-20^{\circ} \mathrm{C}$ until use.

\section{Cell Culture}

Human immortalized C28/I2 cells, were cultured in $25 \mathrm{~cm}^{2}$ flasks with DMEM/HAM's F-12 medium (Biochrom, Berlin, Germany) supplemented with $5 \%$ fetal bovine serum (FBS Superior, Biochrom) and antibiotic-antimycotic solution (100 U/ml penicillin, $0.1 \mathrm{mg} / \mathrm{ml}$ streptomycin, $0.25 \mu \mathrm{g} / \mathrm{ml}$ amphotericin-B; Sigma-Aldrich-Merck). $\mathrm{C} 28 / \mathrm{I} 2$ cells were kept at $37^{\circ} \mathrm{C}$ in a humified atmosphere of $5 \% \mathrm{CO}_{2}$ (standard culture conditions). Subcultures were established once a week until passage 25 .

\section{Acidification Protocol}

To expose C28/I2 cells to different $\mathrm{pH}$ conditions during culture, different cell culture media were prepared as shown in Table $\mathbf{1 .}$ Briefly, $8.3 \mathrm{~g}$ of Dulbecco's Modified Eagle's Medium (DMEM) D5030-1L (Sigma-Aldrich-Merck) powder was dissolved in 
TABLE 1 | Media composition. Concentrations in mM, osmolality in mOsm/kg.

\begin{tabular}{lccccc}
\hline $\mathbf{p H}$ & $\mathbf{7 . 4}$ & $\mathbf{6 . 6}$ & $\mathbf{6 . 0}$ & $\mathbf{5 . 5}$ & $\mathbf{5 . 2}$ \\
\hline $\mathrm{NaHCO}_{3}{ }^{-}$ & 25.0 & 7.5 & 3.5 & 1.5 & 0.8 \\
$\mathrm{HEPES}-\mathrm{FA}$ & 5.0 & 0.0 & 0.0 & 0.0 & 0.0 \\
$\mathrm{MES}-\mathrm{FA}$ & 0.0 & 5.0 & 5.0 & 5.0 & 5.0 \\
$\mathrm{NaCl}$ & 0.0 & 14.0 & 15.0 & 15.0 & 15.0 \\
\hline Osmolality & 299.0 & 300.0 & 299.0 & 300.0 & 303.0
\end{tabular}

distilled water and supplemented with D-glucose $(3.15 \mathrm{~g} / \mathrm{l})$, sodium-pyruvate $(0.06 \mathrm{~g} / \mathrm{l})$ and L-glutamine $(0.37 \mathrm{~g} / \mathrm{l})$. $\mathrm{NaHCO}_{3}$ was added according to the required $\mathrm{pH}$. For acidic media $(\mathrm{pH} \leq 6.6)$ MES free acid (FA) was used instead of HEPES FA. The osmolality was adjusted by the addition of $\mathrm{NaCl}$. The $\mathrm{pH}$, which was measured in the incubator under standard culture conditions, achieved a stable value approximately after $2 \mathrm{~h}$ and remained constant for at least $24 \mathrm{~h}$.

\section{Patch Clamp}

C28/I2 cells were seeded on $0.01 \%$ poly-D-lysine (PDL)-coated coverslips (12 mm diameter) and cultured for at least $24 \mathrm{~h}$ in DMEM/HAM's F-12 medium. Coverslips were transferred to a RC-25 recording chamber (Warner Instruments, Hamden, CT, United States) and mounted on a Nikon Eclipse TE2000-U inverted microscope. Experiments were performed at room temperature in the whole cell perforated patch clamp mode adding $130 \mu \mathrm{M}$ amphotericin to the pipette solution. Recordings were started as soon as the serial resistance was below $30 \mathrm{M} \Omega$. The resistances of the patch electrode were between 4 and $9 \mathrm{M} \Omega$. After establishing the whole-cell configuration, cells were superfused with an extracellular solution and data were recorded using an EPC-10 amplifier controlled by PatchMaster software (HEKA, Lambrecht/Pfalz, Germany). Voltage clamp recordings of $\mathrm{Cl}^{-}$currents under neutral and acidic conditions were performed under symmetrical intra- and extracellular $\mathrm{Cl}^{-}$conditions. The extracellular solution consisted of (in $\mathrm{mM}$ ): $\mathrm{NaCl} 100, \mathrm{CaCl}_{2}$ 2.5, $\mathrm{MgCl}_{2} 2.5$, HEPES FA 10 and mannitol $90(300 \mathrm{mOsm} / \mathrm{kg}$, $\mathrm{pH} 7.2$ adjusted with $\mathrm{NaOH}$ ). In our patch clamp experiments we did not use MES to buffer the $\mathrm{pH}$, because the relatively high flow rate of the perfusion system $(3-5 \mathrm{ml} / \mathrm{min})$ apparently prevents significant $\mathrm{pH}$ deviations in the proximity of the cell. Mannitol was omitted to obtain a hypotonic $(220 \mathrm{mOsm} / \mathrm{kg})$ solution for VSOR current activation. To assess $\mathrm{pH}$ dependent effects, the extracellular solution was titrated with $\mathrm{HCl}$ to a $\mathrm{pH}$ of 6.0. The pipette solution contained (in $\mathrm{mM}$ ): $\mathrm{CsCl} 100, \mathrm{MgCl}_{2} 5$, HEPES FA 10, EGTA 11, raffinose 60, Mg-ATP 2 (303 mOsm $/ \mathrm{kg}$, pH 7.2 adjusted with $\mathrm{CsOH}$ ). The currents were monitored in response to voltage ramps (500 ms duration, 10 -s intervals) and voltage steps ( $500 \mathrm{~ms}$ duration, increments of $20 \mathrm{mV}$ ) from $-100 \mathrm{mV}$ to $+100 \mathrm{mV}$. The holding potential between the ramps/steps was $0 \mathrm{mV}$ to desensitize voltage-activated currents. Bath solution exchange was performed with a valve-controlled gravity-driven perfusion system (ALA Scientific Instruments, Farmingdale, NY, United States) at a flow rate of $3-5 \mathrm{ml} / \mathrm{min}$.

\section{Cell Volume Measurements}

C28/I2 cells were harvested by Trypsin/EDTA after growing under standard conditions. The cell suspension was split into aliquots, which were centrifuged for $4 \mathrm{~min}$ at $200 \times \mathrm{g}$. The supernatants were discarded. Immediately before the first measurement (time point 0 ) the cell pellet was re-suspended in $20 \mathrm{ml}$ of an extracellular solution. For experiments shown in Figure 1G, the solution contained (in $\mathrm{mM}): \mathrm{NaCl} 100, \mathrm{KCl} 5.6, \mathrm{CaCl}_{2} 2.5, \mathrm{MgCl}_{2} 1.5$, HEPES FA 10, MES FA 5, glucose 4.5, and mannitol 80 (300 mOsm $/ \mathrm{kg})$. Mannitol was omitted to obtain a hypotonic $(220 \mathrm{mOsm} / \mathrm{kg})$ solution. For experiments shown in Figures 7A-F, the extracellular solution contained $140 \mathrm{mM} \mathrm{NaCl}$ without mannitol $(300 \mathrm{mOsm} / \mathrm{kg})$. A hypertonic extracellular solution $(360 \mathrm{mOsm} / \mathrm{kg})$ was obtained by the addition of mannitol. The $\mathrm{pH}$ of the extracellular solution was adjusted to 7.4 or 6.0 with $\mathrm{NaOH}$ or $\mathrm{HCl}$, respectively. VSOR $\mathrm{Cl}^{-}$ current inhibitors (NPPB, DCPIB, niflumic acid (NFA), Tamoxifen and DIDS) and the apoptosis inducer staurosporine, which was used to induce AVD, were added to the extracellular solutions as indicated in the individual experiments. Samples in the absence of VSOR $\mathrm{Cl}^{-}$ inhibitors and staurosporine were complemented by a corresponding amount of the solvent (DMSO). The mean cell volumes (MCV in femtoliters) in the different samples were alternately measured on a Beckman Coulter Z2 particle counter (Beckman Coulter, Krefeld, Germany). In the first set of experiments (Figure 1G) samples were measured every $5 \mathrm{~min}$ for $60 \mathrm{~min}$, in the experiments shown in Figure 7A samples were measured every $5 \mathrm{~min}$ for the first $15 \mathrm{~min}$ and every $15 \mathrm{~min}$ for the next $105 \mathrm{~min}$ and in the experiments depicted in Figures 7C,E samples were measured every $10 \mathrm{~min}$ for $60 \mathrm{~min}$. The principle of the measurement is based on changes in electrical resistance produced by nonconductive particles suspended in an electrolyte solution (Coulter method). Calibration for particle size was performed using $10 \mu \mathrm{m}$ Flow-Check fluorospheres (Beckman-Coulter). Data were analyzed with the Multisizer Software (Beckman Coulter) using a 600-fl cutoff to exclude cell debris.

\section{Cell Viability Assays}

C28/I2 cells were seeded at a density of $1 \times 10^{4}$ cells per well into a transparent 96-well microplate (CytoOne; Starlab, Hamburg, Germany). After $24 \mathrm{~h}$, the medium was replaced by serum-free medium (-FBS) and cells were grown for another $24 \mathrm{~h}$ before treatment. For treatment, the medium was replaced by media with different $\mathrm{pH}$ values, $\mathrm{VSOR} \mathrm{Cl}^{-}$current inhibitors and staurosporine concentrations, as indicated in the individual experiments. Samples in the absence of $\mathrm{VSOR} \mathrm{Cl}^{-}$channel inhibitors and staurosporine were complemented by a corresponding amount of the solvent (DMSO). After a treatment period of 8 and $24 \mathrm{~h}$ (incubation), cell viability was measured in a 96well microplate using the resazurin (7-Hydroxy-3H-phenoxazin-3one-10-oxide sodium salt; Sigma-Aldrich-Merck) assay, CellTiterFluor assay or the CellTiter-Glo assay (Promega, Mannheim, Germany). For the resazurin assay the culture supernatant was removed and replaced by $100 \mu \mathrm{l}$ serum-free medium containing $0.5 \mathrm{mM}$ resazurin (stock solution $2.5 \mathrm{mM}$ in PBS). After the incubation of $1 \mathrm{~h}$ at $37^{\circ} \mathrm{C}$ and $5 \% \quad \mathrm{CO}_{2}$ the viability was measured by detecting the fluorescence of the product (resorufin) at $\lambda_{\mathrm{ex}}=535 \mathrm{~nm}$ and $\lambda_{\mathrm{em}}=595 \mathrm{~nm}$ using a Tecan Spark microplate 

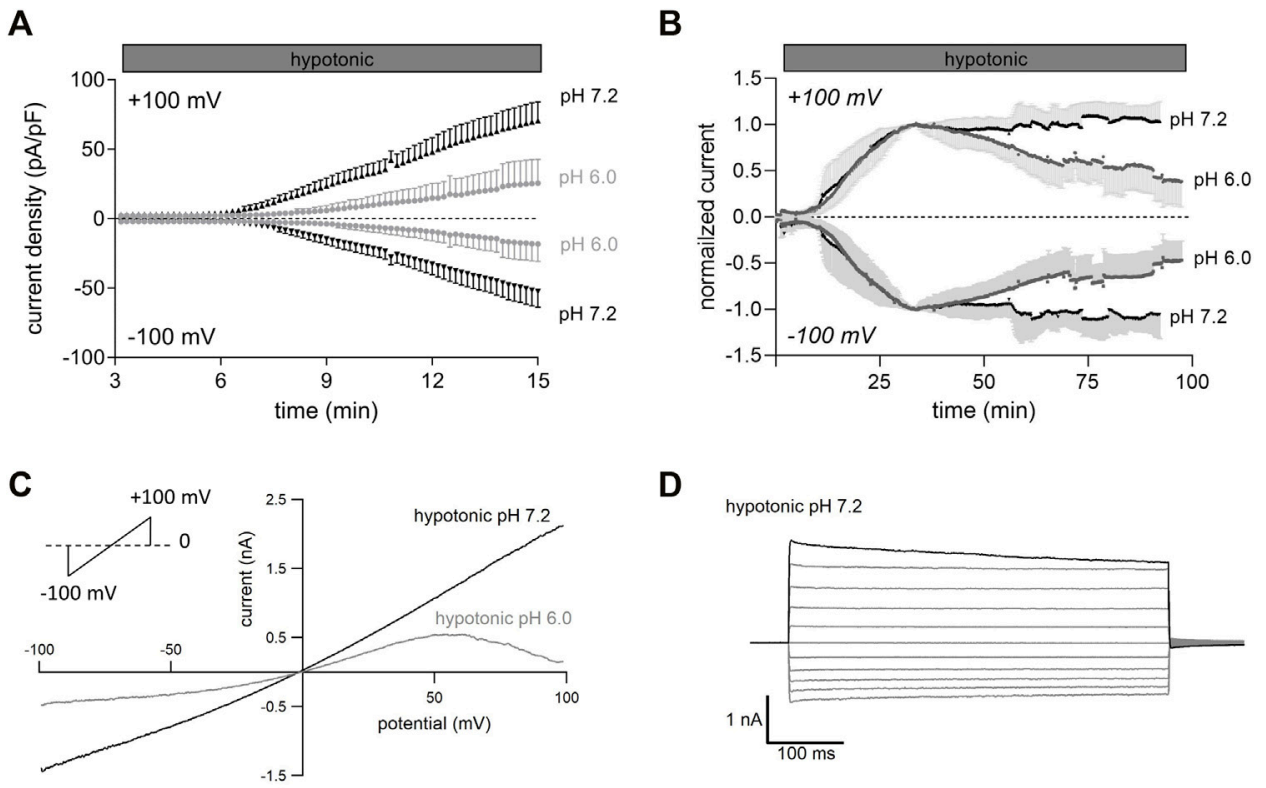

D
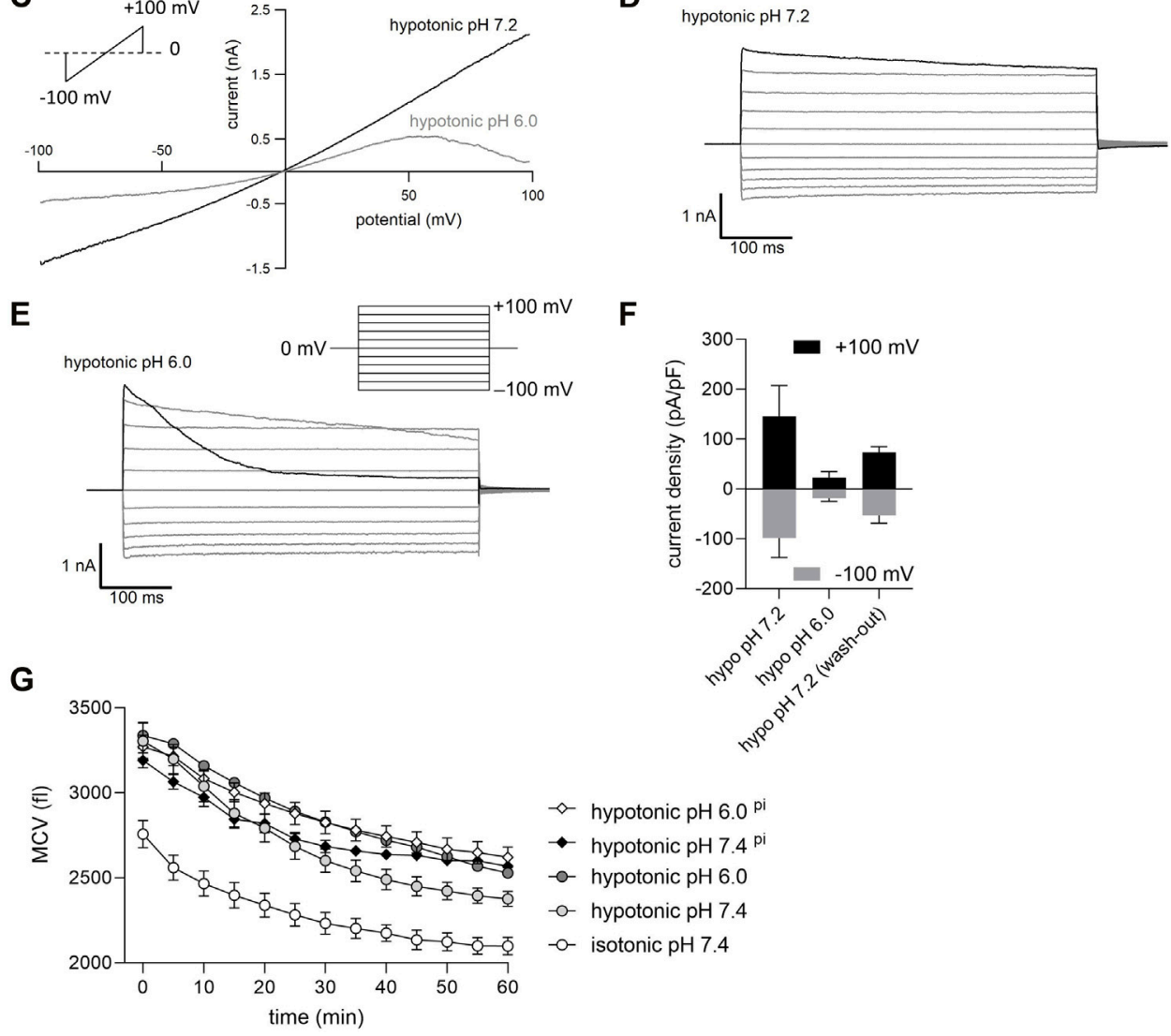

$\diamond$ hypotonic $\mathrm{pH} 6.0^{\mathrm{pi}}$

$\rightarrow$ hypotonic $\mathrm{pH} 7.4^{\mathrm{pi}}$

-o- hypotonic $\mathrm{pH} 6.0$

-o- hypotonic $\mathrm{pH} 7.4$

-o- isotonic $\mathrm{pH} 7.4$

FIGURE 1 Extracellular acidification inhibits VSOR $\mathrm{Cl}^{-}$currents and impairs RVD in $\mathrm{C} 28 / 12$ cells. (A) Mean $\mathrm{Cl}^{-}$current $\pm \mathrm{SEM}$ measured over 15 min under pH 7.2 and $\mathrm{pH} 6.0$ conditions. $24 \mathrm{~h}$ before $\mathrm{Cl}^{-}$currents were measured chondrocytes were preincubated in pH 7.4 medium (control, dark grey triangles), or in pH 6.0 medium (light grey circles). Each symbol represents the current normalized to cell membrane capacity (current density), which was obtained every $10 \mathrm{~s}$ at $+100 \mathrm{mV}$ (upper traces) and $-100 \mathrm{mV}$ (lower traces) in response to 500-ms voltage ramps applied every $10 \mathrm{~s}$ from a holding potential of $0 \mathrm{mV}(\mathrm{n}=6-8)$. (B) Time course of mean $\mathrm{Cl}^{-}$current amplitudes under hypotonic pH 7.2 and pH 6.0 conditions. $\mathrm{pH} 6.0$ solution was applied when $\mathrm{Cl}^{-}$currents reached a maximum under hypotonic conditions. Currents were normalized to peak values under hypotonic conditions. Each circle represents the current at $+100 \mathrm{mV}$ (upper traces) and $-100 \mathrm{mV}$ (lower traces) measured in response to 500-ms voltage ramps applied every $10 \mathrm{~s}$ from a holding potential of $0 \mathrm{mV}(\mathrm{n}=6-7)$. (C) Representative current voltage relationship (500-s voltage ramps applied from $-100 \mathrm{mV}$ to $+100 \mathrm{mV}$ ) recorded under hypotonic $\mathrm{pH} 7.2$ and hypotonic $\mathrm{pH} 6.0$ conditions. (D) and (E) Representative VSOR Cl${ }^{-}$current traces elicited by 500 -ms voltage steps from $-100 \mathrm{mV}$ to $+100 \mathrm{mV}$ in $20-\mathrm{mV}$ increments from a holding potential of $0 \mathrm{mV}$, obtained at pH 7.2 and pH 6.0 as indicated. (F) Peak current densities (pA/pF) at $+100 \mathrm{mV}$ and $-100 \mathrm{mV}$ under hypotonic conditions (hypo pH 7.2), after 75-100 min at hypotonic pH 6.0 (hypo pH 6.0) and after reapplication of hypo pH 7.2 solution (wash-out). (G) Mean cell volume (MCV) \pm SEM in femtoliters (fl) measured over $1 \mathrm{~h}$ under isotonic (300 mOsm/kg) or hypotonic (220 mOsm/kg) conditions at pH 7.4 or pH $6.0(\mathrm{n}=4-8)$. For two conditions - hypotonic $\mathrm{pH} 7.4^{\mathrm{pi}}$ and hypotonic $\mathrm{pH} 6.0^{\mathrm{pi}}$ (diamonds) - cells were preincubated in an acidic medium $(\mathrm{pH}$ 6.0) for $24 \mathrm{~h}$. For the other conditions - isotonic $\mathrm{pH} 7.4$, hypotonic $\mathrm{pH} 7.4$ and hypotonic pH 6.0 (circles), cells were incubated with the same media but under pH 7.4. 
reader (Tecan, Grödig, Austria). CellTiter-Fluor and the CellTiterGlo assays were performed according to the manufacturer's protocols. Fluorescence (CellTiter-Fluor; $\lambda_{\mathrm{ex}}=380 \mathrm{~nm}$ and $\lambda_{\mathrm{em}}=$ $505 \mathrm{~nm}$ ) and luminescence (CellTiter-Glo) were measured using a Tecan Spark microplate Reader. Mean viability values were corrected for blank values (without cells). All treatments were measured at least in triplicate wells.

\section{Caspase 3/7 Activity}

Like for cell viability assays, $1 \times 10^{4}$ cells per well were seeded into a transparent 96-well microplate (CytoOne). After $24 \mathrm{~h}$, the medium was replaced by serum-free medium, and cells were grown for another $24 \mathrm{~h}$ before treatment. After two different treatment periods of 8 and $24 \mathrm{~h}, 50 \mu \mathrm{l}$ of Caspase-Glo 3/7 assay substrate (Promega) was added and cells were incubated for another $30 \mathrm{~min}$. Then the well contents were transferred to a white-walled 96-well plate (Greiner bio-one, Germany). Luminescence was measured in a Tecan Spark multimode reader (Tecan). All treatments were measured at least in triplicates.

\section{Annexin-V/7-Actinomycin D Staining}

For assessment of phosphatidylserine exposure at the cell surface by annexin- $\mathrm{V}$ binding and cell membrane integrity by $7-\mathrm{AAD}$ staining, $1.5 \times 10^{5}$ cells were seeded in $35 \mathrm{~mm}$ diameter Petri dishes. After a cell cultivation period of $24 \mathrm{~h}$ under standard conditions the medium was changed to serum-free medium (-FBS). The following day, cells were incubated for $5 \mathrm{~h}$ under different $\mathrm{pH}$ conditions and staurosporine concentrations, as indicated in the individual experiments. Samples in the absence of staurosporine were treated with an equivalent amount of solvent (DMSO). Thereafter, the cells were harvested and the annexin-V/7-AAD assay was performed following the manufacturer's protocol (BioLegend, San Diego, CA, United States) and measured by flow cytometry on a Cell Lab Quanta SC flow cytometer (Beckman Coulter). Data were analyzed using the FLOWJO software (Becton, Dickinson and Company; Franklin Lakes, NJ, United States).

\section{Data Presentation}

Data are expressed as means \pm standard error of the means (SEM) of at least three independent biological replicates $(n \geq 3)$. In all experimental series, solvent control samples were included. Data were analyzed and plotted using GraphPad Prism 9 (GraphPad Software, La Jolla, CA, United States) or Igor Pro 8 (WaveMetrics, Portland, OR, United States).

\section{RESULTS}

\section{Extracellular Acidification Affects the Functional Activity of Volume-Sensitive Outwardly Rectifying $\mathrm{Cl}^{-}$Channels and Impairs Cell Volume Regulation in Chondrocytes}

In most cells including chondrocytes, cell swelling leads to the activation of distinct anion channels (VSOR channels) and gives rise to a typical swelling activated $\mathrm{Cl}^{-}$current $\left(\mathrm{ICl}_{\text {swell }}\right)$. In C28/I2 cells under hypotonic conditions the current slowly developed over time at $\mathrm{pH} 7.2$ (Figure 1A) and the current-voltage relationship revealed a moderate outward rectification and a (slight) time-dependent inactivation at constant positive holding potentials $(+100 \mathrm{mV})$ (Figure 1D). Time-dependent inactivation was more pronounced shortly after exposing cells to an acidic $\mathrm{pH}$ of 6.0 (Figure 1E). Continued exposure to $\mathrm{pH} 6.0$ and hypotonic conditions led to a progressive decline in the current amplitude until the current was almost abolished after $90 \mathrm{~min}$ (Figures 1B,C). Preincubation for $24 \mathrm{~h}$ of C28/I2 cells under acidic ( $\mathrm{pH}$ 6.0) conditions prior to a hypotonic $\mathrm{pH} 6.0$ challenge decreased the $\mathrm{Cl}^{-}$current amplitude after 15 min by $\sim 75 \%$ and delayed the onset of current activation by $\sim 3 \mathrm{~min}$, as compared to control conditions (Figure 1A). As shown in Figure 1F, perfusion of cells with hypotonic pH 7.2 extracellular solution after 75-100 min of current deactivation under $\mathrm{pH} 6.0$ led to $\sim 40 \%$ current recovery. Considering that VSOR currents are crucial for regulating the cell volume, by extruding anions and/or organic osmolytes and osmotically obliged water to counteract osmotic cell swelling we performed cell volume measurements in C28/I2 cells under isotonic, hypotonic, and acidic conditions to test whether there is a difference in the cells' volume regulating ability at low $\mathrm{pH}$. Under isotonic $\mathrm{pH} 7.4$ (control) conditions we observed a moderate cell shrinkage of $\sim 24 \%$ from a mean cell volume (MCV) of $\sim 2,750 \mathrm{fl}$ to $\sim 2,100 \mathrm{fl}$ over $60 \mathrm{~min}$ (Figure 1G). Under hypotonic $\mathrm{pH} 7.4$ conditions the $\mathrm{MCV}$ at the first timepoint $(0 \mathrm{~min})$ was $\sim 550 \mathrm{fl}$ higher than under isotonic conditions. Over $60 \mathrm{~min}$ this difference in MCV progressively decreased to $\sim 250 \mathrm{fl}$, indicative for RVD. In cells exposed to an acidic and hypotonic (hypotonic $\mathrm{pH}$ 6.0) condition, the difference in MCV to isotonic conditions remained constant over $60 \mathrm{~min}$, indicating a missing RVD response under low $\mathrm{pH}$. Similarly, a $24 \mathrm{~h}$ preincubation of cells at $\mathrm{pH} 6.0$ (indicated as ${ }^{\mathrm{pi}}$ ), impaired the RVD under hypotonic $\mathrm{pH} 6.0$ conditions and under hypotonic $\mathrm{pH} 7.4$ (Figure 1G).

\section{Pharmacological Properties of Volume-Sensitive Outwardly Rectifying $\mathrm{Cl}^{-}$ Channels}

We quantified the sensitivity of the VSOR $\mathrm{Cl}^{-}$current to five different $\mathrm{Cl}^{-}$channel inhibitors-niflumic acid (NFA), DCPIB, DIDS, NPPB and Tamoxifen. To this end VSOR $\mathrm{Cl}^{-}$currents were activated by $80 \mathrm{mOsm} / \mathrm{kg}$ reduction in extracellular osmolality until a plateau was reached. As shown in Figures 2A,B the most selective and potent VSOR channel blockers in C28/I2 cells were Tamoxifen and NPPB, which almost fully blocked the inward and the outward current at concentrations of 10 and $100 \mu \mathrm{M}$, respectively. DIDS at $100 \mu \mathrm{M}$ inhibited the outward current at $+100 \mathrm{mV}$ to $13 \pm 3 \%$ similar to Tamoxifen and NPPB, while the inward current at $-100 \mathrm{mV}$ was less sensitive to DIDS with an inhibition to $39 \pm$ $13 \%$. At a concentration of $500 \mu \mathrm{M}$ niflumic acid (NFA) potently inhibited the inward and outward $\mathrm{Cl}^{-}$current to $15 \pm 5 \%$ and $18 \pm$ $7 \%$, respectively, while at a concentration of $100 \mu \mathrm{M}$, NFA was insufficient to inhibit the current. DCPIB, which is regarded as a 


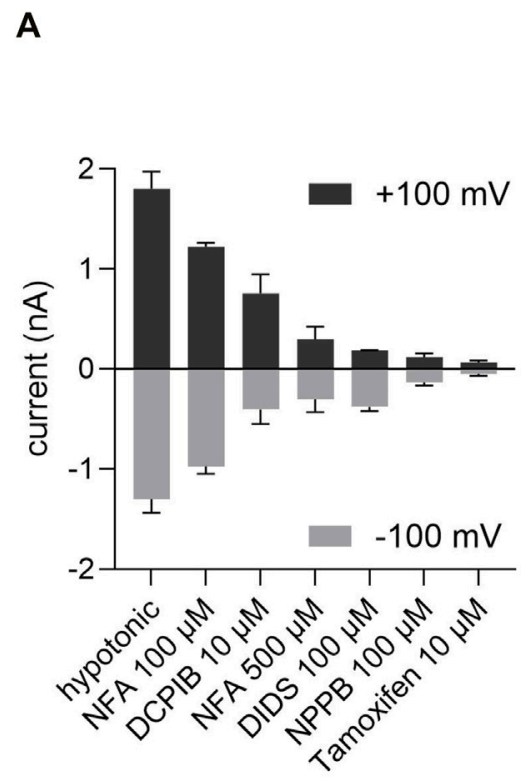

B

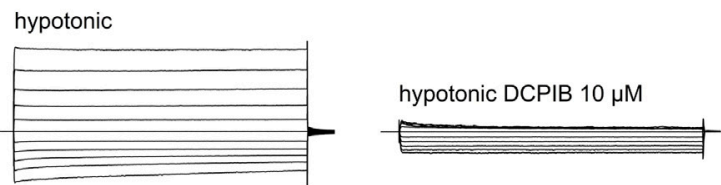

hypotonic

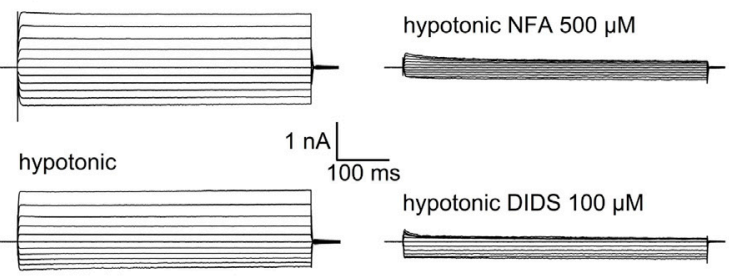

hypotonic

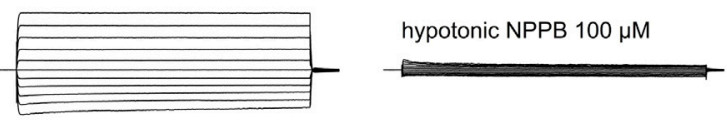

hypotonic

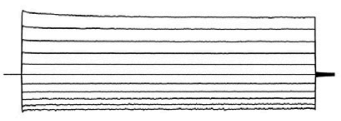

hypotonic Tamoxifen $10 \mu \mathrm{M}$

FIGURE 2 |Pharmacological properties of VSOR $\mathrm{Cl}^{-}$channels in C28/I2 cells. (A) Mean peak VSOR Cl${ }^{-}$current amplitudes $\pm \mathrm{SEM}$ at $+100 \mathrm{mV}$ and $-100 \mathrm{mV}$ under hypotonic conditions in the absence and presence of different inhibitors. (B) VSOR Cl${ }^{-}$current traces elicited by $500-\mathrm{ms}$ voltage steps from $-100 \mathrm{mV}$ to $+100 \mathrm{mV}$ obtained at maximal VSOR Cl- current amplitudes under hypotonic conditions in the absence and presence of DCPIB (10 $\mu \mathrm{M})$, niflumic acid (NFA; $500 \mu \mathrm{M})$, DIDS $(100 \mu M)$, NPPB $(100 \mu M)$ and Tamoxifen $(10 \mu M)(n=3)$.

strong and selective VSOR channel blocker (Pedersen et al., 2016; Friard et al., 2017; Okada et al., 2019), was far less potent in chondrocytes compared to the other inhibitors tested, showing an inhibition to $35 \pm 5 \%$ at $+100 \mathrm{mV}$ and $30 \pm 4 \%$ at $-100 \mathrm{mV}$.

\section{Acidic Preconditioning Protects Chondrocytes Against Staurosporine-Induced Apoptosis}

In a next set of experiments, we examined the effect of different extracellular $\mathrm{pH}(7.4,6.6,6.0,5.5$ and 5.2$)$ on caspase $3 / 7$ activity after treatment with the apoptosis inducer staurosporine (st) $(5 \mu \mathrm{M})$. Under control conditions $(\mathrm{pH} 7.4)$ in the absence of staurosporine, a low caspase 3/7 activity was measured in C28/I2 cells, which slightly decreased, when cells were incubated for $8 \mathrm{~h}$ in acidic media ( $\mathrm{pH} \mathrm{6.0,5.5} \mathrm{and} \mathrm{5.2)} \mathrm{(Figure} \mathrm{3A).} \mathrm{Exposure} \mathrm{to}$ $5 \mu \mathrm{M}$ staurosporine for $8 \mathrm{~h}$ elicited a $\mathrm{pH}$-dependent $1.5-3$ fold increase in the caspase $3 / 7$ activity. The maximum of caspase $3 / 7$ activity was observed under $\mathrm{pH} 7.4$ conditions after staurosporine treatment, which decreased progressively with decreasing $\mathrm{pH}$ (6.6, 6.0, 5.5 and 5.2). Cell viability was assessed by resazurin, CellTiter-Glo and CellTiter-Fluor assays. The CellTiter-Fluor assay measures a constitutive protease activity within living cells whereas resazurin and CellTiter-Glo assays are based on the quantitation of ATP present in metabolically active cells. For all three methods the results were similar. In resazurin assays the cell viability within $8 \mathrm{~h}$ of treatment with $5 \mu \mathrm{M}$ staurosporine dropped in a $\mathrm{pH}$-dependent manner, with a strong reduction in the viability at $\mathrm{pH} 7.4$ and progressively less reduction in cell viability from $\mathrm{pH} 6.6$ to $\mathrm{pH} 5.5$ and 5.2 (Figure 3B). Viability was $\sim 5 \%$ under $\mathrm{pH} 7.4$ plus $5 \mu \mathrm{M}$ staurosporine, while it was over $65 \%$ in low pH media (5.5 and 5.2), compared to their controls in the absence of staurosporine (Figure 3B). The effect was similar in CellTiter-Glo assays showing $\sim 48 \%$ viability under $\mathrm{pH} 5.5$ in the presence of staurosporine compared to $\sim 4 \%$ at $\mathrm{pH} 7.4+$ st (Figure 3C). Compared with resazurin and CellTiter-Glo assays, in CellTiter-Fluor measurement the ratio of viable cells was higher in presence of staurosporine compared to the respective controls $(\sim 40 \%, 56 \%$ and $\sim 86 \%$ at $\mathrm{pH} 7.4,6.0$ and 5.5, respectively) (Figure 3D). This is probably because assessment of cell viability via protease activity using CellTiter-Fluor more selectively reflects the actual number of living cells, while the signal in resazurin and CellTiter-Glo assays is not only proportional to the absolute cell number but also to the cells' metabolic activity and ATP content.

Annexin-V/7-AAD double staining was performed to confirm apoptosis. After a 5 -h treatment with 1 and $5 \mu \mathrm{M}$ staurosporine under $\mathrm{pH} 7.4$ conditions, there was a decline in the Q4 annexinV-/7-AAD- (living) cell population accompanied by a 5 fold ( $1 \mu \mathrm{M}$ staurosporine) and 6.5 fold $(5 \mu \mathrm{M}$ staurosporine) increase in the Q3 annexin-V+/7-AAD- (early apoptotic) population (Figures 4C,D and Figures 5A,B). This staurosporine-induced decline in the Q4 annexin-V-/7-AAD(living) cell population and increase in the Q3 annexin- $\mathrm{V}+/ 7$ - 


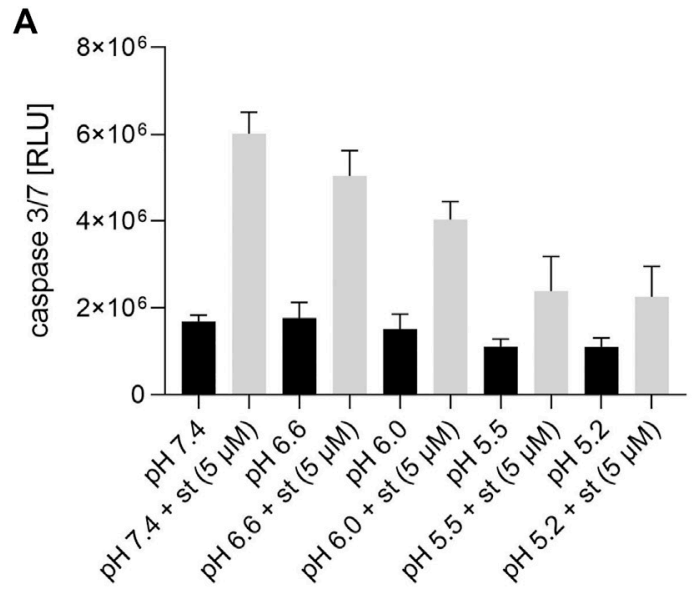

C

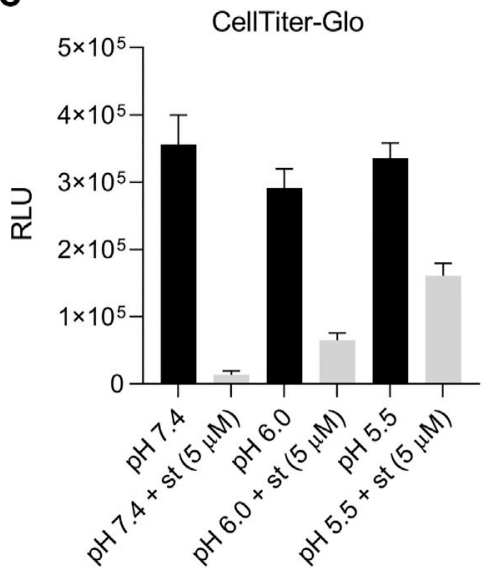

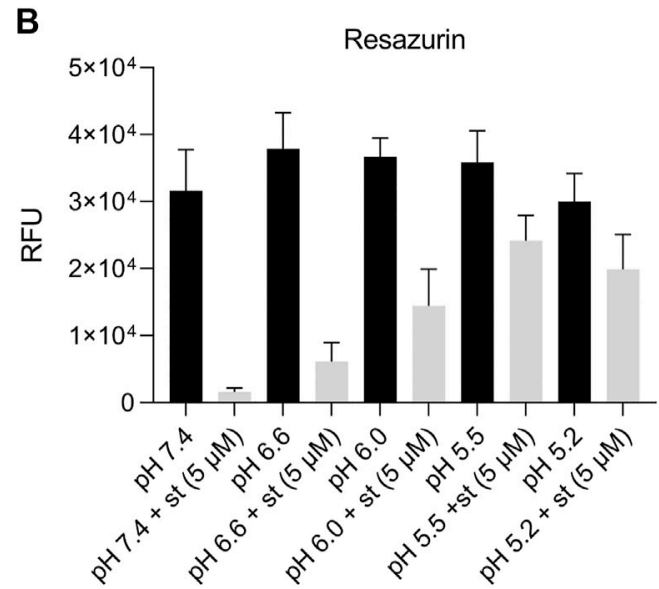

D

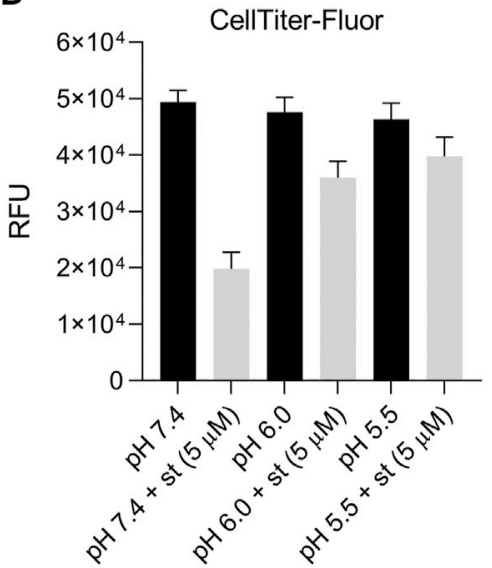

FIGURE 3 | Effect of acidic preconditioning on caspase 3/7 activity and cell viability. (A) Caspase 3/7 activity and viability assessed by (B) resazurin and (C) CellTiter-Glo assays based on the cells' metabolic activity and ATP content and (D) CellTiter-Fluor assays based on constitutive protease activity in living cells. C28/I2 cells were kept for $8 \mathrm{~h}$ at different $\mathrm{pH}$ values in the absence or presence of staurosporine (st) $(5 \mu \mathrm{M})(\mathrm{n}=3)$.

AAD- (early apoptotic) cell population was reversed under acidic conditions ( $\mathrm{pH} 5.5$ ), showing $\sim 85 \%$ living cells and $\sim 10 \%$ early apoptotic cells, which was similar to control conditions ( $\mathrm{pH} 7.4$ without st) (Figures 4C,D and Figures 5C,D). The effects of staurosporine and acidification were less pronounced in the Q2 Annexin-V+/7-AD+ (late apoptotic) and Q1 annexin-V-/7$\mathrm{AAD}+$ (necrotic) cell populations (Figures $\mathbf{4 A}, \mathbf{B}$ and Figures 5A-D).

To test whether the protective effect of low $\mathrm{pH}$ in C28/I2 cells is associated with VSOR channel activity, we investigated the effects of $\mathrm{Cl}^{-}$channel inhibitors on staurosporine-induced apoptosis. NFA $(500 \mu \mathrm{M})$, NPPB $(100 \mu \mathrm{M})$ and DIDS $(100 \mu \mathrm{M})$ attenuated apoptosis induced by $1 \mu \mathrm{M}$ staurosporine, as evidenced by a decreasing caspase $3 / 7$ activity and an increasing viability compared to controls in the absence of the VSOR $\mathrm{Cl}^{-}$channel inhibitors (Figures 6A-D). However, while the reduction in caspase activity under staurosporine was comparable between the three inhibitors and exposure to $\mathrm{pH}$ 5.0 , the increase in viability was less evident for NFA and NPPB as compared to DIDS and pH 5.0. DCPIB ( 5 or $10 \mu \mathrm{M})$ did not affect caspase 3/7 activity and viability at $\mathrm{pH} 7.4$ in the absence or presence of staurosporine (Figures 6A,B) but caused a decrease in staurosporine-induced caspase activity and a strong reduction in cell viability at $\mathrm{pH} 6.0$ (Figures 6E,F). Tamoxifen at $10 \mu \mathrm{M}$ showed similar effects as DCPIB on caspase activity in both absence and presence of staurosporine (Figure 6A) but caused a drastic decline in cell viability in the presence of the apoptosis inducer (Figure 6B). In addition, annexin-V/7-AAD double staining revealed that DIDS $(100 \mu \mathrm{M})$ increased the Q4 annexin-V-/7-AAD- (living) cell population by $\sim 20 \%$ and decreased the Q3 annexin-V+/7-AAD- (early apoptotic) cell population of $\sim 20 \%$ after staurosporine treatment $(1 \mu \mathrm{M})$ compared to cells treated with staurosporine alone in the absence of DIDS ( $\mathrm{pH} 7.4+$ st $(1 \mu \mathrm{M})$ ) (Figures 4C,D and Figure 5F). DIDS had no effect on the Q4 annexin-V-/7AAD - (living) and Q3 annexin V+/7-AAD- (early apoptotic) cell populations, when cells were exposed to $5 \mu \mathrm{M}$ staurosporine (Figures 4C,D). In comparison to control (pH 7.4), DIDS alone had no effect on the Q1-Q4 distribution of annexin-V/7-AAD double stained cells (Figures 4A-D and Figure 5E). 
A

Q1 Annexin-V-/7-AAD+
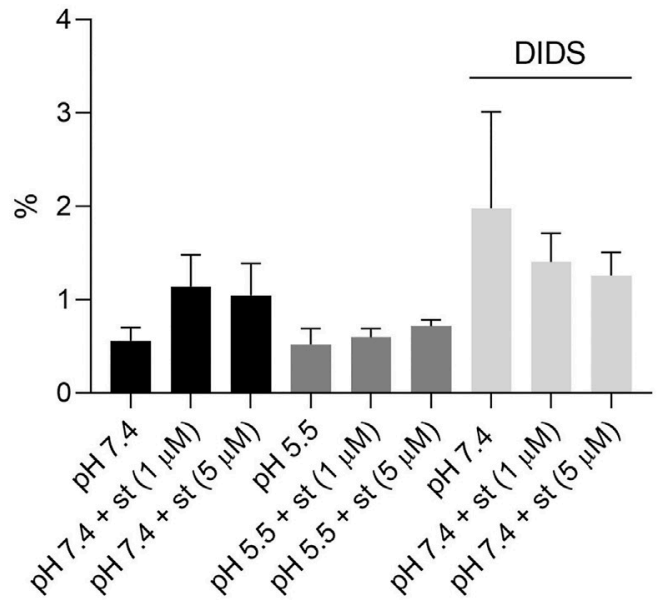

C

Q4 Annexin-V-/7-AAD-

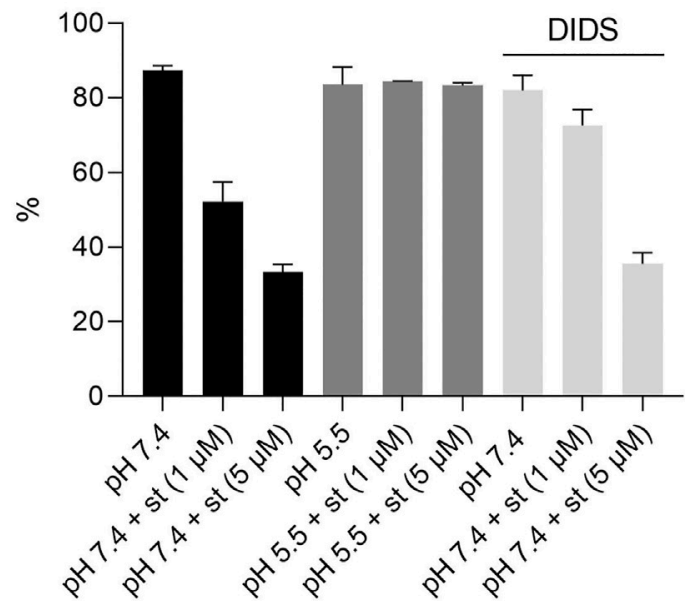

B

Q2 Annexin-V+/7-AAD+
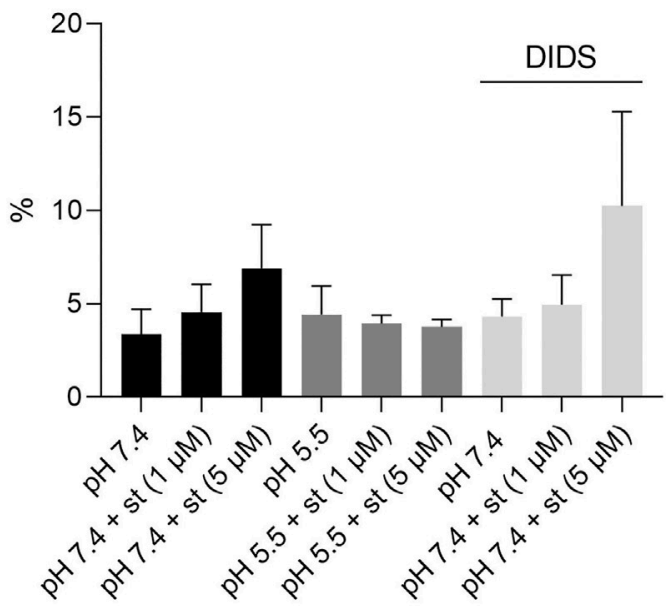

D

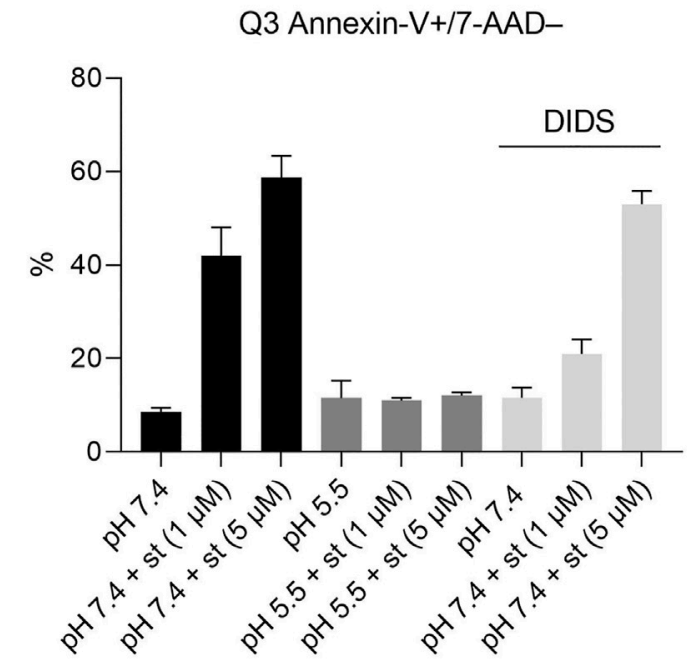

FIGURE 4 | Effect of acidic preconditioning on annexin V/7-AAD staining. Annexin V/7-AAD staining of C28/l2 cells after $5 \mathrm{~h}$ incubation under neutral pH 7.4, acidic pH 5.5 and neutral pH 7.4 + DIDS (100 $\mu \mathrm{M})$ conditions in the absence and presence of staurosporine (st) (1 and $5 \mu \mathrm{M})$. (A) Q1 annexin-V-/7-AAD+ (necrotic cells) (B) Q2 annexin-V+/7-AAD+ (late apoptotic cells) (C) Q4 annexin-V-/7-AAD- (living cells), (D) Q3 annexin-V+/7-AAD- (early apoptotic cells) (n = 4).

\section{Acidic Conditions and Volume-Sensitive Outwardly Rectifying $\mathrm{Cl}^{-}$Channel Inhibitors Prevent Staurosporine-Induced Normotonic Cell Shrinkage}

As shown in Figure $\mathbf{7 A}$, the exposure of C28/I2 cells to staurosporine $(5 \mu \mathrm{M})$ resulted in a reduction of the $\mathrm{MCV}$. Application of a hypertonic solution $(360 \mathrm{mOsm} / \mathrm{kg})$ also induced cell shrinkage, but in contrast to the staurosporineinduced cell shrinkage, the decline in the cell volume was more pronounced at earlier timepoints and flattened after $\sim 30 \mathrm{~min}$, suggesting the induction of a regulatory volume increase (RVI) response. The staurosporine-induced AVD was completely abolished under pH 6.0. After 60 and 120 min under isotonic $\mathrm{pH} 7.4$ + staurosporine the $\mathrm{MCV}$ was $\sim 120$ and $-250 \mathrm{fl}$ lower compared to cells kept under isotonic pH 7.4 (Figure 7A and depicted as $\triangle \mathrm{MCV}$ in Figure $7 \mathbf{B}$ ), whereas at $\mathrm{pH} 6.0$ there was no difference measured after $60 \mathrm{~min}$ and after $120 \mathrm{~min}$ the difference in MCV was only -50 fl. In further experiments we tested for the effects of $\mathrm{Cl}^{-}$channel blockers on the time course of staurosporine-induced AVD. These experiments were performed under isotonic conditions and $\mathrm{pH}$ 7.4. On average, staurosporine induced an AVD $(\triangle \mathrm{MCV})$ of $\sim-300 \mathrm{fl}$ over $60 \mathrm{~min}$ versus control (Figures 7C-F). All tested inhibitors but Tamoxifen reduced the AVD after 60 min between cells kept in the absence and presence of staurosporine. Under NPPB $(100 \mu \mathrm{M})$, DCPIB $(10 \mu \mathrm{M})$, NFA $(500 \mu \mathrm{M})$ and DIDS $(100 \mu \mathrm{M})$ the $\Delta \mathrm{MCV}$ was $\sim-100,-150,-50$ 
A

A $\quad \mathrm{pH} 7.4$

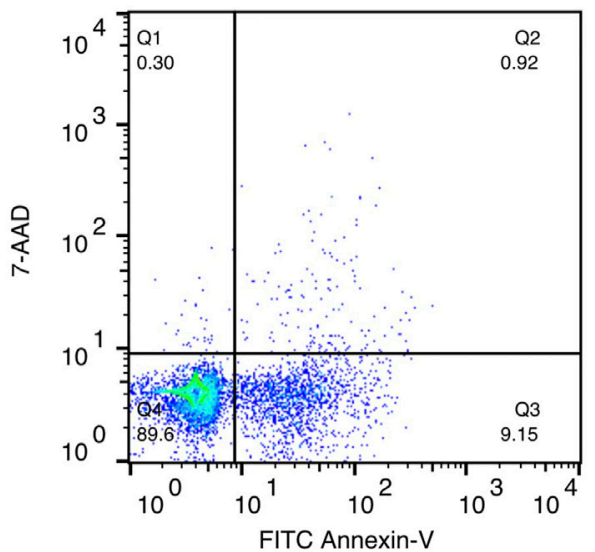

C

pH 5.5

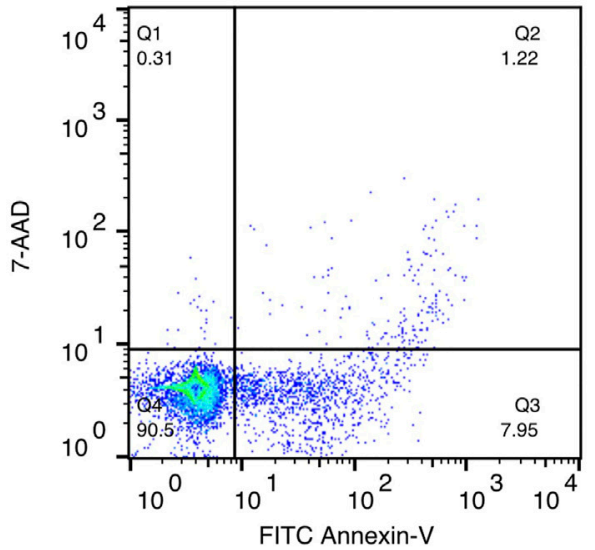

E

pH 7.4 DIDS (100 $\mu \mathrm{M})$

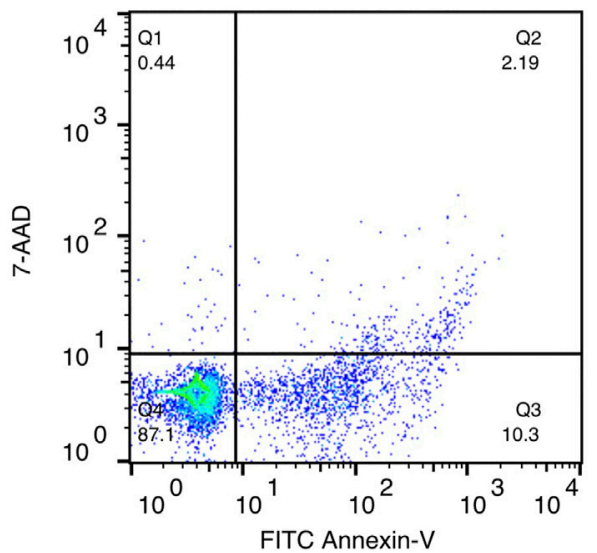

B $\quad \mathrm{pH} 7.4 \mathrm{st}(1 \mu \mathrm{M})$

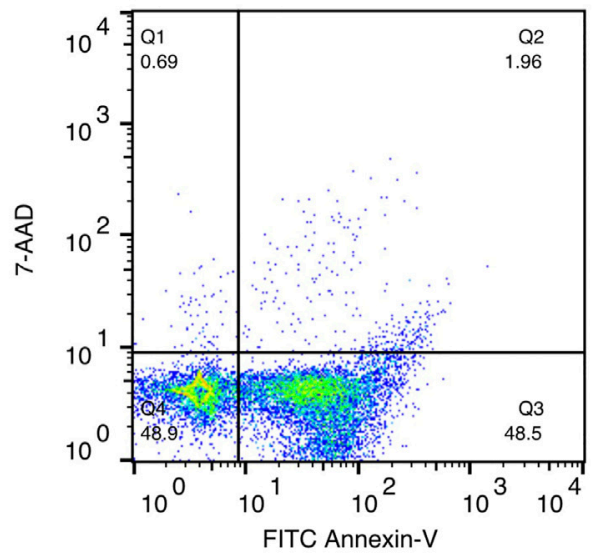

D $\mathrm{pH} 5.5$ st $(1 \mu \mathrm{M})$

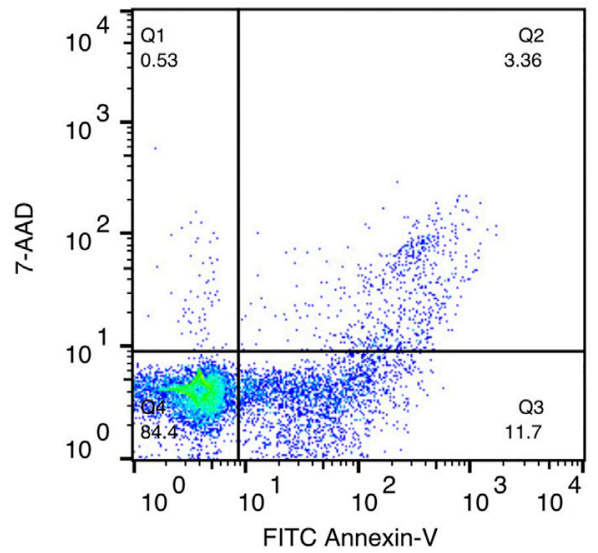

$\mathbf{F}$
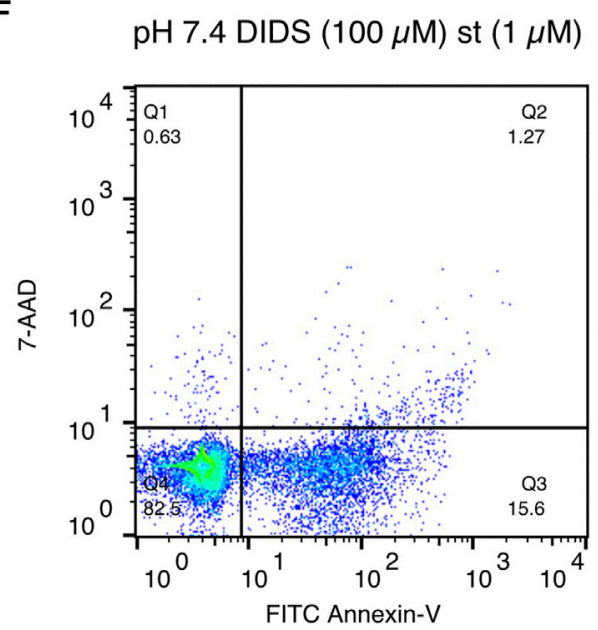

FIGURE 5 | Exemplary annexin V/7-AAD staining scatter plots after $5 \mathrm{~h}$ of incubation in media of (A) $\mathrm{pH} 7.4$, (B) $\mathrm{pH} 7.4$ with staurosporine (st) (1 $\mu$ M), (C) $\mathrm{pH} 5.5$,

(D) $\mathrm{pH} 5.5$ with staurosporine $(1 \mu \mathrm{M})$, (E) $\mathrm{pH} 7.4$ in presence of DIDS $(100 \mu \mathrm{M})$ and $\mathbf{( F )} \mathrm{pH} 7.4$ with staurosporine in presence of DIDS (100 $\mu \mathrm{M})$. 

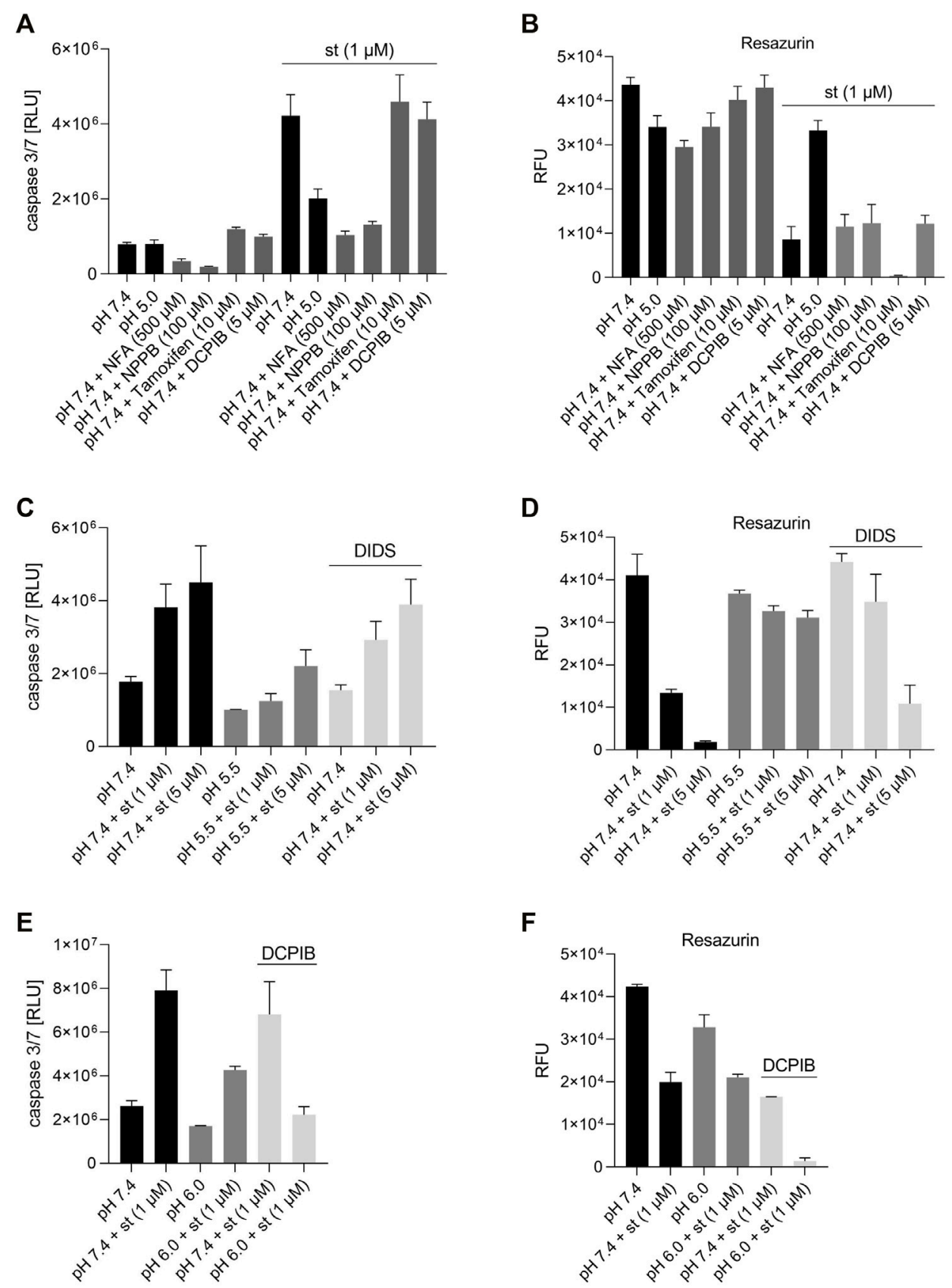

FIGURE 6 | Effect of different VSOR $\mathrm{Cl}^{-}$channel inhibitors on caspase $3 / 7$ activity and cell viability. (A) Caspase $3 / 7$ activity and (B) viability of C28/12 cells treated for $6 \mathrm{~h}$ with pH 7.4, $\mathrm{pH} 5.5$ and pH 7.4 + different VSOR Cl${ }^{-}$current inhibitors in the absence and presence of staurosporine (st) $(1 \mu \mathrm{M})(\mathrm{n}=3)$. (C) Caspase $3 / 7$ activity and (D) viability of C28/I2 cells treated for $8 \mathrm{~h}$ with pH 7.4, pH 5.5 and pH 7.4 + DIDS $(100 \mu \mathrm{M})$ in the absence or presence of staurosporine (st) $(1 \mathrm{and} 5 \mu \mathrm{M})(\mathrm{n}=4)$. (E) Caspase $3 / 7$ activity and $\mathbf{( F )}$ viability of cells treated for $24 \mathrm{~h}$ with $\mathrm{pH} 7.4$ and $\mathrm{pH} 6.0$ with or without $\mathrm{DCPIB}(10 \mu \mathrm{M})$ in the absence or presence of staurosporine (st) $(1 \mu M)(n=2-3)$. Data are represented as mean \pm SEM.

and $-150 \mathrm{fl}$, respectively. Cells kept under $10 \mu \mathrm{M}$ Tamoxifen showed a strong decline in the MCV after $30 \mathrm{~min}$ and signs of cell death under the microscope (not shown). After $60 \mathrm{~min}$ the MCV was higher in cells exposed to Tamoxifen + staurosporine as compared to cells in presence of Tamoxifen alone (Figures 7C,D). By using flow cytometry, we assessed the MCV after $5 \mathrm{~h}$.
The data show that the AVD induced by $1 \mu \mathrm{M}$ (cell shrinkage from $\sim 1,850$ to $\sim 1,450 \mathrm{fl}$ ) and $5 \mu \mathrm{M}$ staurosporine (cell shrinkage from $\sim 1,850$ to $\sim 1,300 \mathrm{fl}$ ) was completely abolished under $\mathrm{pH} 5.5$ and was attenuated by the $\mathrm{Cl}^{-}$channel inhibitor DIDS $(100 \mu \mathrm{M})$ at $1 \mu \mathrm{M}$ (cell shrinkage from $\sim 1,800$ to $\sim 1,620 \mathrm{fl}$ ) but not at $5 \mu \mathrm{M}$ staurosporine (Figure 7G). 


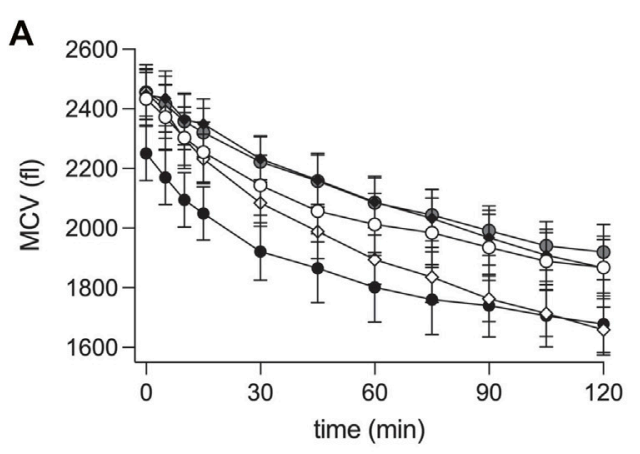

C

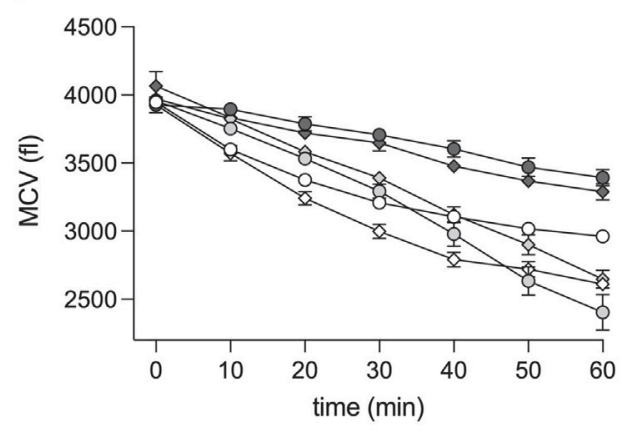

E

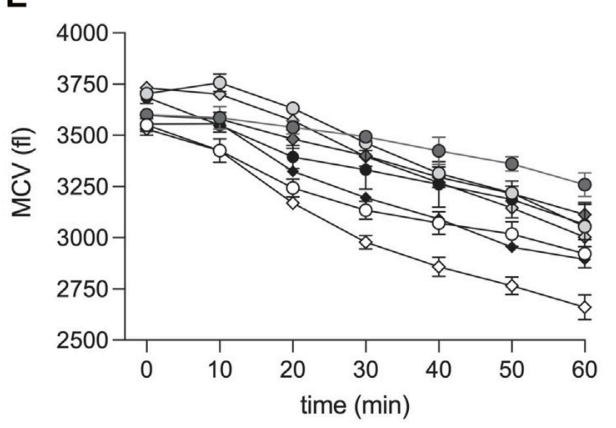

G

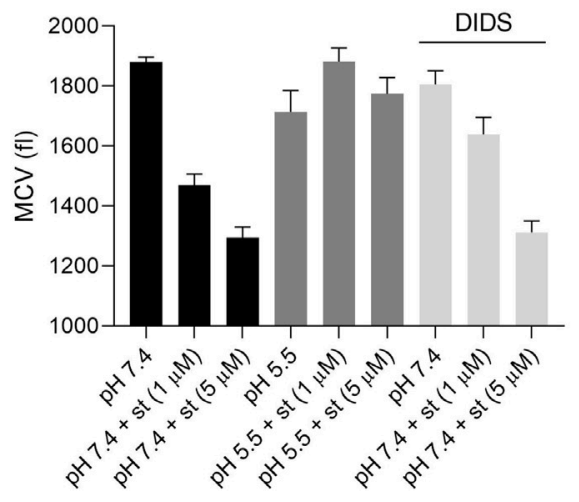

- - isotonic $\mathrm{pH} 6.0$

- - isotonic pH $6.0+$ st $(5 \mu \mathrm{M})$

-o- isotonic $\mathrm{pH} 7.4$

$\diamond$ isotonic $\mathrm{pH} 7.4+$ st $(5 \mu \mathrm{M})$

hypertonic $\mathrm{pH} 7.4$

\section{B}

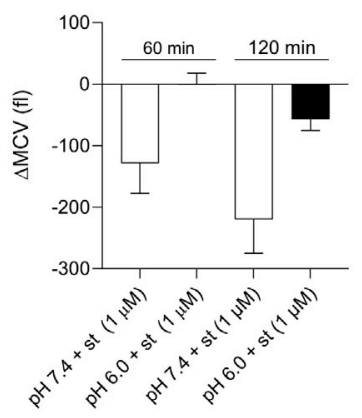

D

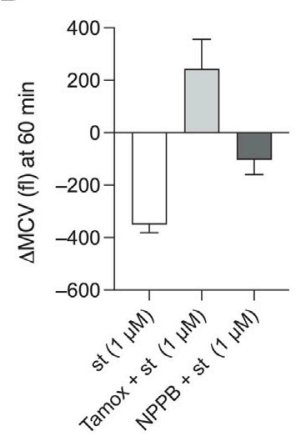

F

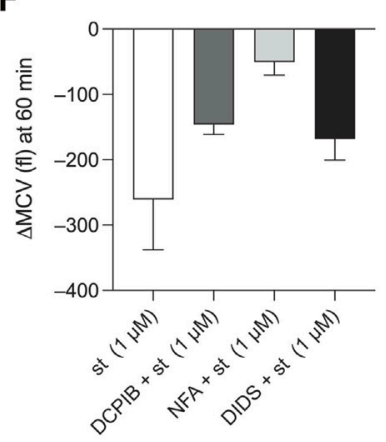

FIGURE 7|AVD in chondrocytes is impaired under acidic conditions and in the presence of VSOR Cl-channel inhibitors. (A, C, E) Mean cell volume (MCV) \pm SEM in femtoliters (fl) measured (A) over $2 \mathrm{~h}$ under hypertonic $(360 \mathrm{mOsm} / \mathrm{kg}) \mathrm{pH} 7.4$ conditions and under isotonic $(300 \mathrm{mOsm} / \mathrm{kg}) \mathrm{conditions}$ at pH 7.4 or pH 6.0 in the presence and absence of $5 \mu \mathrm{M}$ staurosporine $(\mathrm{st})(\mathrm{n}=4)$ and $(\mathbf{C}, \mathbf{E}) \mathrm{MCV}$ measured over 60 min under isotonic $\mathrm{pH} 7.4 \mathrm{conditions}$ in the absence (control) or presence of the $\mathrm{Cl}^{-}$channel inhibitors NPPB $(100 \mu \mathrm{M})$, Tamoxifen (Tamox) $(10 \mu \mathrm{M})$, DCPIB $(10 \mu \mathrm{M})$, niflumic acid (NFA; $\left.500 \mu \mathrm{M}\right)$ or DIDS $(100 \mu \mathrm{M}) \pm$ staurosporine $(1 \mu \mathrm{M})(\mathrm{n}=$

3). (B) Differences in MCV ( $\triangle \mathrm{MCV}$ in fl) calculated from data in (A) at the timepoints 60 and 120 min for matching $\mathrm{pH}$ conditions (pH 7.4 and 6.0$)$ in the presence and absence of staurosporine. (D, F) $\triangle \mathrm{MCV}$ at $60 \mathrm{~min}$ calculated from data in (C, E) for control (absence of blockers) and matching blocker conditions in the presence and absence of $1 \mu \mathrm{M}$ staurosporine. (G) MCV \pm SEM assessed by using flow cytometry after $5 \mathrm{~h}$ of incubation with $\mathrm{pH} 7.4, \mathrm{pH} 7.4+\mathrm{DIDS}$ (100 $\mu \mathrm{M}$ ) and pH 5.5 in the presence and absence of staurosporine (st) $(1 \mu \mathrm{M}$ or $5 \mu \mathrm{M})(\mathrm{n}=4)$. 


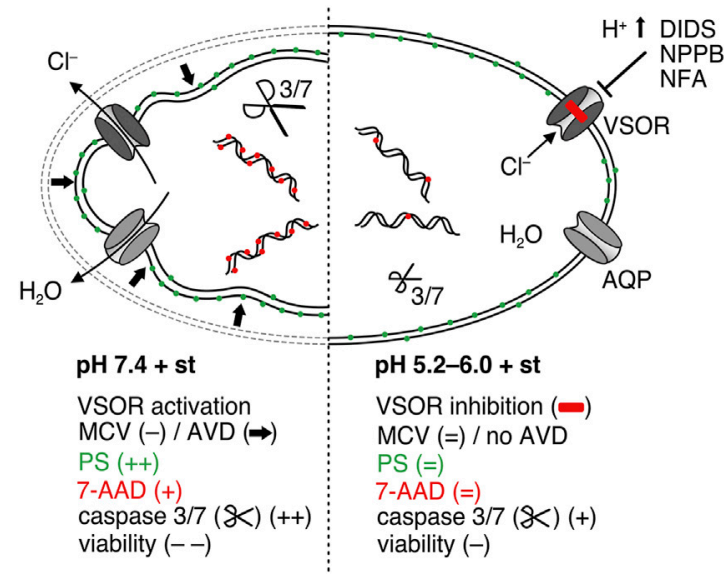

FIGURE 8 | Putative model of the antiapoptotic effect of acidosis in C28/12 cells treated with staurosporine. Under pH 7.4 (left side) staurosporine (st) treatment leads to activation of volume-sensitive outwardly rectifying (VSOR) $\mathrm{Cl}^{-}$channels to induce cell shrinkage (AVD), which is an initial step during apoptosis, followed by phosphatidylserine (PS) exposure, caspase activation, DNA fragmentation, membrane blebbing and loss of membrane integrity evidenced by the 7-AAD uptake. Under acidic conditions (right side) VSOR channels are deactivated so that AVD is absent under isotonic conditions and consequently apoptosis is suppressed in the presence of staurosporine.

\section{DISCUSSION}

The results of the present study show that extracellular acidosis deactivates VSOR channels and protects chondrocytes from apoptosis. Specifically, we demonstrated that low $\mathrm{pH}$ reduces the caspase $3 / 7$ activity and increases the viability after exposing C28/I2 cells to the apoptosis inducer staurosporine, as illustrated in Figure 8. Although the protective effect of acidosis against apoptosis has been shown in different cell types, very little is known about the underlying mechanisms. However, $\mathrm{Ca}^{2+}$ signaling, tyrosine kinase receptor Axl expression and mitochondrial ATP production have been suggested to play a role in the protective effect of acidosis (D'Arcangelo et al., 2002; Terminella et al., 2002; Sharma et al., 2005). E.g., in osteoclasts, the protective effect of acidosis against apoptosis was shown to be mediated by a rise in the intracellular $\mathrm{Ca}^{2+}$ concentration through proton-sensing receptor ovarian cancer $G$ protein-coupled receptor 1 (OGR1) signalling (Pereverzev et al., 2008). To the best of our knowledge, this is the first report that VSOR currents are likely to be important for the acidosis-induced antiapoptotic effect in chondrocytes.

We show that lowering the $\mathrm{pH}$ to 6.0 leads to gradual deactivation of the volume-sensitive outwardly rectifying (VSOR) $\mathrm{Cl}^{-}$current. Immediately after lowering the $\mathrm{pH}$, an accelerated time-dependent inactivation at high positive potentials was observed, which is in line with earlier results obtained in Xenopus oocytes (Ackerman et al., 1994), C6 glioma cells (Jackson and Strange, 1995), BC3H1 mouse myoblasts (Voets et al., 1997), or bovine pulmonary artery cells (Nilius et al., 1998) and might be interpreted as the onset phase of acid-induced VSOR current deactivation. In addition, we showed recently in chondrocytes and microglial cells that a strong acidification to $\mathrm{pH} \leq 5.0$ causes a fast and complete deactivation of the VSOR current and simultaneous activation of an acidsensitive outwardly rectifying (ASOR) $\mathrm{Cl}^{-}$current (also termed proton-activated $\mathrm{Cl}^{-}$current/channel; PAC or PACC) (Kittl et al., 2019a; Kittl et al., 2020). To prevent ASOR current activation, in the present study we therefore avoided acidification below $\mathrm{pH}$ 5.0. The mechanism underlying acidity-induced deactivation of the VSOR $\mathrm{Cl}^{-}$current over time is unknown. It might be caused by conformational changes of the channel protein itself after proton binding, altered interaction with regulatory factors, or altered expression of channel entities. Until recently, the molecular identity of the VSOR channel remained obscure and has been controversially debated (Pedersen et al., 2015). Meanwhile there is compelling evidence from gene-silencing studies that leucinerich repeat containing 8 (LRRC8) family members A-E are essential components of VSOR channels (Pedersen et al., 2015; Jentsch, 2016; Jentsch et al., 2016), but it is still possible, that additional proteins are involved in channel formation and/or regulation of VSOR channel activity (Okada et al., 2020). With respect to long-term exposure to staurosporine or hypoosmotic conditions, previous studies suggest that changes in VSOR channel activity are more likely caused by modulation of the function of LRRC8 channel proteins rather than by their abundance (Bach et al., 2018; Yurinskaya et al., 2020). To date there is no information available on the $\mathrm{pH}$-sensitivity of LRRC8 proteins on the expressional and/or functional level. This needs to be addressed in future studies.

Apoptotic volume decrease (AVD) is an early event in apoptosis, which starts before caspase activation and DNA fragmentation and is characterized by a normotonic shrinkage of cells (Okada and Maeno, 2001; Elmore, 2007; Poulsen et al., 2010; Maeno et al., 2012; Okada et al., 2020). The inhibition of the VSOR $\mathrm{Cl}^{-}$current has been shown to prevent drug-induced AVD and the following steps of apoptosis induced by activation of either the intrinsic or extrinsic pathway (Maeno et al., 2000; Okada et al., 2001; Ernest et al., 2008). Specifically, the reduction in the intracellular $\mathrm{Cl}^{-}$concentration during AVD is essential for the activation of DNA fragmentation factors (Rasola et al., 1999; Dupere-Minier et al., 2004). In the present study, staurosporine induced an AVD within $30 \mathrm{~min}$, which was completely absent under acidic conditions ( $\mathrm{pH} 6.0$ and 5.5). We also observed that not only the AVD but also the RVD was impaired by acidity, which supports the assumption, that the induction of AVD under normotonic conditions and RVD under hypotonic conditions share common volume regulatory mechanisms including VSOR $\mathrm{Cl}^{-}$current activation (Maeno et al., 2000). Furthermore, an involvement of the VSOR $\mathrm{Cl}^{-}$channel in AVD is supported by the findings that 1) AVD was abolished by pharmacological inhibition of $\mathrm{Cl}^{-}$channels and (Maeno et al., 2000; Okada et al., 2006), 2) inducers of apoptosis like staurosporine, doxorubicin, FAS ligand, TNFa, or $\mathrm{H}_{2} \mathrm{O}_{2}$ activate VSOR $\mathrm{Cl}^{-}$ channels (D’anglemont De Tassigny et al., 2004; Porcelli et al., 2004; Shimizu et al., 2004; Jiao et al., 2006) and 3) apoptotic cells undergoing AVD display RVD facilitation (Maeno et al., 2000). In a study on salmonid hepatoma and gill cells, DIDS, an inhibitor of $\mathrm{Cl}^{-}$channels, partially suppressed AVD 
(Krumschnabel et al., 2007), while Maeno et al. and Jiao et al. observed a complete suppression (Jiao et al., 2006; Maeno et al., 2012). In addition, $\mathrm{Cl}^{-}$channel blockers like NPPB and phloretin have also been reported to inhibit AVD completely whereas SITS, niflumic acid (NFA) and glibenclamide have been shown to attenuate AVD. In line with these previous findings, in our present work we observed a reduction in the AVD response in C28/I2 cells by DIDS, NPPB, NFA and DCPIB. The same blockers have also been described to prevent ischemiainduced, serum deprivation-induced and drug-induced apoptotic cell death in various cells including endothelial cells (D’Arcangelo et al., 2000; D’Arcangelo et al., 2002; Kumar et al., 2008), liver cells (Currin et al., 1991), lymphoblastic cells (Bohloli et al., 2016), neurons (Xu et al., 1998) and tumor cells (Akbar and Kim, 2002; Sharma et al., 2005). In the present volume experiments, we observed a cell shrinkage over time under isotonic conditions and normal $\mathrm{pH}$, which has similarly been described in human epithelial cells, cortical neurons, insulinoma cells and microglial cells (Jakab et al., 2006; Wang et al., 2007; Sato-Numata et al., 2014; Kittl et al., 2019a). As already discussed in our previous paper (Kittl et al., 2019a), this might be caused by an imbalance in osmolality under the given conditions with relative hypertonicity of the extracellular solution.

$\mathrm{Cl}^{-}$channel blockers have also been found to reduce apoptosis in cells treated by the anti-cancer drug cisplatin (Cai et al., 2015). Only a few studies challenge the concept that AVD is an early prerequisite of apoptosis leading to cell death, by showing that $\mathrm{VSOR} \mathrm{Cl}{ }^{-}$channel blockers inhibited AVD without preventing apoptotic cell death. For example, in RAW 264.7 macrophages and cortical neurons, VSOR channel blockers prevented AVD, whereas apoptotic cell death was not or only mildly attenuated (Hortelano et al., 2002; Wei et al., 2004). Our study in human chondrocytes provides evidence, that acidosis has a similar anti-apoptotic effect like pharmacological inhibition of VSOR $\mathrm{Cl}^{-}$channels. We assume that acidosis gradually deactivates VSOR $\mathrm{Cl}^{-}$currents, which-by preventing AVD-impedes the progression of apoptosis evidenced by a higher viability in chondrocytes after staurosporine treatment (Figure 8). Interestingly, in the present study pharmacological inhibition of VSOR $\mathrm{Cl}^{-}$current with DIDS, NPPB and NFA was less protective than acidosis, indicating that the protective effect of acidosis in chondrocytes is not solely based on the inhibition of $\mathrm{Cl}^{-}$currents. A major shortcoming of $\mathrm{Cl}^{-}$channel blockers in their commonly used concentrations is their lack in specificity, which compromises their explanatory potential. VSOR channel inhibitors like DIDS and NPPB also block other cell volume-correlated anion channels such as Maxi- $\mathrm{Cl}^{-}$channels and acid-sensitive outwardly rectifying (ASOR) channels (Friard et al., 2017; Kittl et al., 2019a; Kittl et al., 2020; Okada et al., 2021). DCPIB has also been shown to inhibit $\mathrm{K}^{+}$ channels involved in cell volume regulation such as TWIK and TASK K2P channels (Lv et al., 2019).

Indeed, a number of studies have linked apoptosis not only to $\mathrm{Cl}^{-}$channels but also to other ion channels (Hoffmann et al., 2009). $\mathrm{K}^{+}$and $\mathrm{Na}^{+}$, critical determinants of cell volume, have been proposed to play a role in apoptosis. For example, the $\mathrm{K}^{+}$ channel blockers tetraethylammonium (TEA) and clofilium effectively attenuated AVD as well as apoptotic cell death in cortical neurons (Wei et al., 2004). Also, intracellular $\mathrm{Ca}^{2+}$ is tightly linked to apoptosis. As an example, it has been shown that a cytoplasmic $\mathrm{Ca}^{2+}$ overload by increasing the L-type $\mathrm{Ca}^{2+}$ channel activity triggers apoptosis in endocrine cells (JunttiBerggren et al., 1993). In contrast, the inhibition of T-type $\mathrm{Ca}^{2+}$ channels has been reported to induce p53-dependent apoptosis in colon cancer cells (Dziegielewska et al., 2014). Some of the channels, which are involved in apoptosis, are known to be $\mathrm{pH}$ sensitive (Delisle and Satin, 2000; Petho et al., 2020), which might add to the anti-apoptotic effect of low $\mathrm{pH}$ explaining the strong anti-apoptotic effect of acidosis and a weaker effect of $\mathrm{Cl}^{-}$channel inhibition alone, as observed in our present study. In addition, the $\mathrm{VSOR} \mathrm{Cl}^{-}$channel inhibitors DCPIB and Tamoxifen were used in the present study to test their effect on apoptosis. Surprisingly, our data suggest that these two inhibitors promote cell death after staurosporine treatment under both acidic and $\mathrm{pH} 7.4$ conditions, while in a study on cardiomyocytes by Wang et al., DCPIB like DIDS inhibited apoptosis and restored viability after treatment with high glucose (Wang et al., 2017). It is important to consider that DCPIB might have significant off-target effects. A recent study demonstrated that DCPIB suppresses mitochondrial respiration independently of VSOR $\mathrm{Cl}^{-}$channel activity (Afzal et al., 2019). We suggest that the exposure to $10 \mu \mathrm{M}$ DCPIB or Tamoxifen for several hours might similarly impair the viability of chondrocytes and promote cell death by exerting cytotoxic effects.

Tissue areas of locally decreased $\mathrm{pH}$ are hallmarks of many diseases or disease-associated conditions. By using surface enhanced Raman spectroscopy, high concentrations of protons could be visualized locally at the cell membrane of gastric tumor cells, with a low surface interstitial $\mathrm{pH}$ of 6.0 (Puppulin et al., 2018). Low local $\mathrm{pH}$ could also be detected under pathological conditions like ischemia (Smith et al., 1986), or atherosclerotic plaques (Naghavi et al., 2002) with $\mathrm{pH}$ values of $\sim 6.5$ and 7.0 , respectively. Patients with rheumatoid arthritis showed significantly lower $\mathrm{pH}$ values of the synovial fluid than healthy subjects (Cummings and Nordby, 1966) and in patients with primary hip $\mathrm{OA}$, intraoperative in situ $\mathrm{pH}$ measurements revealed massive acidification at the cartilage surface to values as low as $\sim 5.5$ at stage 3 (Konttinen et al., 2002). In this pH-range we found reduced apoptotic cell death and a promotion of the survivability of chondrocytes. In vivo, this might contribute to the appearance of hypercellularity of chondrocytes observed in early stages of OA (Galois et al., 2004; Pauli et al., 2011) and in the subsequent degradation in advanced states of OA (Hwang and Kim, 2015). During aging, the number of chondrocytes also increases in the deep layer of cartilage, leading to OA by subchondral tissue calcification or other structural changes of the cartilage (Akkiraju and Nohe, 2015). Interestingly, in one experimental series of the present study shown in Figure 3B, we observed a slightly higher viability under acidic conditions $\geq \mathrm{pH} 5.5$. With respect to cell volume, in an anterior cruciate ligament transection (ACLT) rabbit osteoarthritis model, chondrocytes have shown to be swollen in comparison to controls. Kumagai et al. concluded that this phenomenon was due to a reduced capacity of RVD (Kumagai et al., 2016). Importantly, we show here and in a previous study that cell volume regulation in chondrocytes is impaired under acidic conditions (Kittl et al., 2020). Taken together, impaired RVD, 
prevention of AVD and apoptosis and a higher survivability (hypercellularity) in chondrocytes under acidic conditions may possibly play a role in the onset and/or development of OA.

In summary, this study shows that VSOR $\mathrm{Cl}^{-}$channels are inhibited under acidic conditions. Since $\mathrm{Cl}^{-}$channels are involved in volume regulatory processes like RVD and AVD, cell volume homeostasis and apoptosis are massively deranged, and the viability of chondrocytes is enhanced by acidity. Given that the maintenance of extracellular matrix production and cartilage integrity exclusively depends on the functional stability of chondrocytes, compromised cell volume homeostasis and altered viability are likely to promote articular cartilage degeneration and progression of OA.

\section{DATA AVAILABILITY STATEMENT}

The original contributions presented in the study are included in the article/Supplementary Material, further inquiries can be directed to the corresponding author.

\section{REFERENCES}

Ackerman, M. J., Wickman, K. D., and Clapham, D. E. (1994). Hypotonicity Activates a Native Chloride Current in Xenopus Oocytes. J. Gen. Physiol. 103, 153-179. doi:10.1085/jgp.103.2.153

Afzal, A., Figueroa, E. E., Kharade, S. V., Bittman, K., Matlock, B. K., Flaherty, D. K., et al. (2019). The LRRC8 Volume-regulated Anion Channel Inhibitor, DCPIB, Inhibits Mitochondrial Respiration Independently of the Channel. Physiol. Rep. 7, e14303. doi:10.14814/phy2.14303

Akbar, M., and Kim, H.-Y. (2002). Protective Effects of Docosahexaenoic Acid in Staurosporine-Induced Apoptosis: Involvement of Phosphatidylinositol-3 Kinase Pathway. J. Neurochem. 82, 655-665. doi:10.1046/j.1471-4159.2002.01015.x

Akkiraju, H., and Nohe, A. (2015). Role of Chondrocytes in Cartilage Formation, Progression of Osteoarthritis and Cartilage Regeneration. J. Develop. Biol. 3, 177-192. doi:10.3390/jdb3040177

Bach, M. D., Sørensen, B. H., and Lambert, I. H. (2018). Stress-induced Modulation of Volume-Regulated Anions Channels in Human Alveolar Carcinoma Cells. Physiol. Rep. 6, e13869. doi:10.14814/phy2.13869

Bohloli, M., Atashi, A., Soleimani, M., Kaviani, S., and Anbarlou, A. (2016). Investigating Effects of Acidic $\mathrm{pH}$ on Proliferation, Invasion and DrugInduced Apoptosis in Lymphoblastic Leukemia. Cancer Microenvironment 9, 119-126. doi:10.1007/s12307-016-0187-0

Bortner, C. D., and Cidlowski, J. A. (1996). Absence of Volume Regulatory Mechanisms Contributes to the Rapid Activation of Apoptosis in Thymocytes. Am. J. Physiology-Cell Physiol. 271, C950-C961. doi:10.1152/ ajpcell.1996.271.3.C950

Bortner, C. D., and Cidlowski, J. A. (2004). The Role of Apoptotic Volume Decrease and Ionic Homeostasis in the Activation and Repression of Apoptosis. Pflugers Archiv Eur. J. Physiol. 448 (3), 313-318. doi:10.1007/s00424-004-1266-5

Cai, S., Zhang, T., Zhang, D., Qiu, G., and Liu, Y. (2015). Volume-sensitive Chloride Channels Are Involved in Cisplatin Treatment of Osteosarcoma. Mol. Med. Rep. 11, 2465-2470. doi:10.3892/mmr.2014.3068

Chen, L., König, B., Liu, T., Pervaiz, S., Razzaque, Y. S., and Stauber, T. (2019). More Than Just a Pressure Relief Valve: Physiological Roles of VolumeRegulated LRRC8 Anion Channels. Biol. Chem. 400, 1481-1496. doi:10.1515/hsz-2019-0189

Cummings, N. A., and Nordby, G. L. (1966). Measurement of Synovial Fluid pH in normal and Arthritic Knees. Arthritis Rheum. 9, 47-56. doi:10.1002/art.1780090106

Currin, R. T., Gores, G. J., Thurman, R. G., and Lemasters, J. J. (1991). Protection by Acidotic $\mathrm{pH}$ against Anoxic Cell Killing in Perfused Rat Liver: Evidence for a pH Paradox. FASEB j. 5, 207-210. doi:10.1096/fasebj.5.2.2004664

\section{AUTHOR CONTRIBUTIONS}

Conceptualization, MK, MW, MR, and MJ; Formal analysis, MK, MW, and MJ; Funding acquisition, MK, MW, and MJ; Investigation, MK, MW, JP-P, VS, MG, and MJ; Supervision, MR and MJ; Validation, MK, MW, and MJ; Visualization, MK, MW, and MJ; Writing-original draft, MK, MW, and MJ; Writing-review and editing, MK, MW, MR, and MJ.

\section{FUNDING}

This project was supported by the research support funds of the Paracelsus Medical University, E-19/29/153-KIT to MK.

\section{ACKNOWLEDGMENTS}

We thank Marlena Beyreis and Leman Emin for the skilled technical and administrative assistance.

D'anglemont De Tassigny, A., Souktani, R., Henry, P., Ghaleh, B., and Berdeaux, A (2004). Volume-sensitive Chloride Channels (ICl,vol) Mediate DoxorubicinInduced Apoptosis through Apoptotic Volume Decrease in Cardiomyocytes. Fundam. Clin. Pharmacol. 18, 531-538. doi:10.1111/j.1472-8206.2004.00273.x

D’Arcangelo, D., Facchiano, F., Barlucchi, L. M., Melillo, G., Illi, B., Testolin, L., et al. (2000). Acidosis Inhibits Endothelial Cell Apoptosis and Function and Induces Basic Fibroblast Growth Factor and Vascular Endothelial Growth Factor Expression. Circ. Res. 86, 312-318. doi:10.1161/ 01.res.86.3.312

D’Arcangelo, D., Gaetano, C., and Capogrossi, M. C. (2002). Acidification Prevents Endothelial Cell Apoptosis by Axl Activation. Circ. Res. 91, e4-12. doi:10.1161/ 01.res.0000036753.50601.e9

Delisle, B. P., and Satin, J. (2000). pH Modification of Human T-type Calcium Channel Gating. Biophysical J. 78, 1895-1905. doi:10.1016/S0006-3495(00) 76738-5

Ding, D., Moskowitz, S. I., Li, R., Lee, S. B., Esteban, M., Tomaselli, K., et al. (2000). Acidosis Induces Necrosis and Apoptosis of Cultured Hippocampal Neurons. Exp. Neurol. 162, 1-12. doi:10.1006/exnr.2000.7226

Dupéré-Minier, G., Hamelin, C., Desharnais, P., and Bernier, J. (2004). Apoptotic Volume Decrease, $\mathrm{pH}$ Acidification and Chloride Channel Activation during Apoptosis Requires CD45 Expression in HPB-ALL T Cells. Apoptosis 9, 543-551. doi:10.1023/B:APPT.0000038031.84705.84

Dziegielewska, B., Brautigan, D. L., Larner, J. M., and Dziegielewski, J. (2014). T-type Ca2+ Channel Inhibition Induces P53-dependent Cell Growth Arrest and Apoptosis through Activation of P38-MAPK in Colon Cancer Cells. Mol. Cancer Res. 12, 348-358. doi:10.1158/15417786.MCR-13-0485

Elmore, S. (2007). Apoptosis: a Review of Programmed Cell Death. Toxicol. Pathol. 35, 495-516. doi:10.1080/01926230701320337

Ernest, N. J., Habela, C. W., and Sontheimer, H. (2008). Cytoplasmic Condensation Is Both Necessary and Sufficient to Induce Apoptotic Cell Death. J. Cel Sci. 121, 290-297. doi:10.1242/jcs.017343

Friard, J., Tauc, M., Cougnon, M., Compan, V., Duranton, C., and Rubera, I. (2017). Comparative Effects of Chloride Channel Inhibitors on LRRC8/VRACMediated Chloride Conductance. Front. Pharmacol. 8, 328. doi:10.3389/ fphar.2017.00328

Galois, L., Etienne, S., Grossin, L., Watrin-Pinzano, A., Cournil-Henrionnet, C., Loeuille, D., et al. (2004). Dose-response Relationship for Exercise on Severity of Experimental Osteoarthritis in Rats: a Pilot Study. Osteoarthritis and Cartilage 12, 779-786. doi:10.1016/j.joca.2004.06.008

Harl, B., Schmölzer, J., Jakab, M., Ritter, M., and Kerschbaum, H. H. (2013). Chloride Channel Blockers Suppress Formation of Engulfment 
Pseudopodia in Microglial Cells. Cell Physiol Biochem 31, 319-337. doi:10.1159/000343370

Hoffmann, E. K., Lambert, I. H., and Pedersen, S. F. (2009). Physiology of Cell Volume Regulation in Vertebrates. Physiol. Rev. 89, 193-277. doi:10.1152/ physrev.00037.2007

Hortelano, S., Zeini, M., Castrillo, A., Alvarez, A. M., and Boscá, L. (2002). Induction of Apoptosis by Nitric Oxide in Macrophages Is Independent of Apoptotic Volume Decreas. Cell Death Differ 9, 643-650. doi:10.1038/ sj.cdd. 4401017

Hwang, H., and Kim, H. (2015). Chondrocyte Apoptosis in the Pathogenesis of Osteoarthritis. Int. J. Mol. Sci. 16, 26035-26054. doi:10.3390/ijms161125943

Jackson, P. S., and Strange, K. (1995). Characterization of the Voltage-dependent Properties of a Volume-Sensitive Anion Conductance. J. Gen. Physiol. 105, 661-676. doi:10.1085/jgp.105.5.661

Jakab, M., Grundbichler, M., Benicky, J., Ravasio, A., Chwatal, S., Schmidt, S., et al. (2006). Glucose Induces Anion Conductance and Cytosol-To-Membrane Transposition of ICln in INS-1E Rat Insulinoma Cells. Cel Physiol Biochem 18, 21-34. doi:10.1159/000095131

Jakab, M., and Ritter, M. (2006). Cell Volume Regulatory Ion Transport in the Regulation of Cell Migration. Contrib. Nephrol. 152, 161-180. doi:10.1159/ 000096322

Jentsch, T. J., Lutter, D., Planells-Cases, R., Ullrich, F., and Voss, F. K. (2016). VRAC: Molecular Identification as LRRC8 Heteromers with Differential Functions. Pflugers Arch. - Eur. J. Physiol. 468, 385-393. doi:10.1007/ s00424-015-1766-5

Jentsch, T. J. (2016). VRACs and Other Ion Channels and Transporters in the Regulation of Cell Volume and beyond. Nat. Rev. Mol. Cel Biol. 17, 293-307. doi:10.1038/nrm.2016.29

Jiao, J.-D., Xu, C.-Q., Yue, P., Dong, D.-L., Li, Z., Du, Z.-M., et al. (2006). Volumesensitive Outwardly Rectifying Chloride Channels Are Involved in Oxidative Stress-Induced Apoptosis of Mesangial Cells. Biochem. Biophysical Res. Commun. 340, 277-285. doi:10.1016/j.bbrc.2005.11.175

Juntti-Berggren, L., Larsson, O., Rorsman, P., Ammala, C., Bokvist, K., Wahlander, K., et al. (1993). Increased Activity of L-type Ca2+ Channels Exposed to Serum from Patients with Type I Diabetes. Science 261, 86-90. doi:10.1126/ science.7686306

Kittl, M., Helm, K., Beyreis, M., Mayr, C., Gaisberger, M., Winklmayr, M., et al. (2019a). Acid- and Volume-Sensitive Chloride Currents in Microglial Cells. Ijms 20, 3475. doi:10.3390/ijms20143475

Kittl, M., Jakab, M., Steininger, T. S., Ritter, M., and Kerschbaum, H. H. (2019b). A Swelling-Activated Chloride Current in Microglial Cells Is Suppressed by Epac and Facilitated by PKA - Impact on Phagocytosis. Cel Physiol Biochem 52, 951-969. doi:10.33594/000000066

Kittl, M., Winklmayr, M., Helm, K., Lettner, J., Gaisberger, M., Ritter, M., et al. (2020). Acid- and Volume-Sensitive Chloride Currents in Human Chondrocytes. Front. Cel Dev. Biol. 8, 583131. doi:10.3389/fcell.2020.583131

Kondratskyi, A., Kondratska, K., Skryma, R., and Prevarskaya, N. (2015). Ion Channels in the Regulation of Apoptosis. Biochim. Biophys. Acta (Bba) Biomembranes 1848, 2532-2546. doi:10.1016/j.bbamem.2014.10.030

Konttinen, Y. T., Mandelin, J., Li, T.-F., Salo, J., Lassus, J., Liljeström, M., et al. (2002). Acidic Cysteine Endoproteinase Cathepsin K in the Degeneration of the Superficial Articular Hyaline Cartilage in Osteoarthritis. Arthritis Rheum. 46, 953-960. doi:10.1002/art.10185

Krumschnabel, G., Maehr, T., Nawaz, M., Schwarzbaum, P. J., and Manzl, C. (2007). Staurosporine-induced Cell Death in Salmonid Cells: the Role of Apoptotic Volume Decrease, Ion Fluxes and MAP Kinase Signaling. Apoptosis 12, 1755-1768. doi:10.1007/s10495-007-0103-7

Kumagai, K., Toyoda, F., Staunton, C. A., Maeda, T., Okumura, N., Matsuura, H., et al. (2016). Activation of a Chondrocyte Volume-Sensitive $\mathrm{Cl}$ - Conductance Prior to Macroscopic Cartilage Lesion Formation in the Rabbit Knee Anterior Cruciate Ligament Transection Osteoarthritis Model. Osteoarthritis and Cartilage 24, 1786-1794. doi:10.1016/j.joca.2016.05.019

Kumar, S., Kasseckert, S., Kostin, S., Abdallah, Y., Schafer, C., Kaminski, A., et al. (2007). Ischemic Acidosis Causes Apoptosis in Coronary Endothelial Cells through Activation of Caspase-12珎. Cardiovasc. Res. 73, 172-180. doi:10.1016/ j.cardiores.2006.09.018

Kumar, S., Reusch, H. P., and Ladilov, Y. (2008). Acidic Pre-conditioning Suppresses Apoptosis and Increases Expression of Bcl-xL in Coronary
Endothelial Cells under Simulated Ischaemia. J. Cel Mol Med 12 1584-1592. doi:10.1111/j.1582-4934.2007.00172.x

Lang, F., Busch, G. L., Ritter, M., Völkl, H., Waldegger, S., Gulbins, E., et al. (1998). Functional Significance of Cell Volume Regulatory Mechanisms. Physiol. Rev. 78, 247-306. doi:10.1152/physrev.1998.78.1.247

Lv, J., Liang, Y., Zhang, S., Lan, Q., Xu, Z., Wu, X., et al. (2019). DCPIB, an Inhibitor of Volume-Regulated Anion Channels, Distinctly Modulates K2P Channels. ACS Chem. Neurosci. 10, 2786-2793. doi:10.1021/ acschemneuro.9b00010

Maeno, E., Ishizaki, Y., Kanaseki, T., Hazama, A., and Okada, Y. (2000). Normotonic Cell Shrinkage Because of Disordered Volume Regulation Is an Early Prerequisite to Apoptosis. Proc. Natl. Acad. Sci. 97, 9487-9492. doi:10.1073/pnas.140216197

Maeno, E., Takahashi, N., and Okada, Y. (2006). Dysfunction of Regulatory Volume Increase Is a Key Component of Apoptosis. FEBS Lett. 580, 6513-6517. doi:10.1016/j.febslet.2006.10.074

Maeno, E., Tsubata, T., and Okada, Y. (2012). Apoptotic Volume Decrease (AVD) Is Independent of Mitochondrial Dysfunction and Initiator Caspase Activation. Cells 1, 1156-1167. doi:10.3390/cells1041156

Naghavi, M., John, R., Naguib, S., Siadaty, M. S., Grasu, R., Kurian, K. C., et al. (2002). pH Heterogeneity of Human and Rabbit Atherosclerotic Plaques; a New Insight into Detection of Vulnerable Plaque. Atherosclerosis 164, 27-35. doi:10.1016/s0021-9150(02)00018-7

Nilius, B., Prenen, J., and Droogmans, G. (1998). Modulation of Volume-Regulated Anion Channels by Extra- and Intracellular pH. Pflugers Archiv Eur. J. Physiol. 436, 742-748. doi:10.1007/s004240050697

Okada, Y., and Maeno, E. (2001). Apoptosis, Cell Volume Regulation and VolumeRegulatory Chloride Channels. Comp. Biochem. Physiol. A: Mol. Integr. Physiol. 130, 377-383. doi:10.1016/s1095-6433(01)00424-x

Okada, Y., Maeno, E., Shimizu, T., Dezaki, K., Wang, J., and Morishima, S. (2001). Receptor-mediated Control of Regulatory Volume Decrease (RVD) and Apoptotic Volume Decrease (AVD). J. Physiol. 532, 3-16. doi:10.1111/ j.1469-7793.2001.0003g.x

Okada, Y., Okada, T., Sato-Numata, K., Islam, M. R., Ando-Akatsuka, Y., Numata, T., et al. (2019). Cell Volume-Activated and Volume-Correlated Anion Channels in Mammalian Cells: Their Biophysical, Molecular, and Pharmacological Properties. Pharmacol. Rev. 71, 49-88. doi:10.1124/ pr.118.015917

Okada, Y., Sabirov, R. Z., Sato-Numata, K., and Numata, T. (2020). Cell Death Induction and Protection by Activation of Ubiquitously Expressed Anion/ Cation Channels. Part 1: Roles of VSOR/VRAC in Cell Volume Regulation, Release of Double-Edged Signals and Apoptotic/Necrotic Cell Death. Front. Cel Dev. Biol. 8, 614040. doi:10.3389/fcell.2020.614040

Okada, Y., Sato-Numata, K., Sabirov, R. Z., and Numata, T. (2021). Cell Death Induction and Protection by Activation of Ubiquitously Expressed Anion/ Cation Channels. Part 2: Functional and Molecular Properties of ASOR/ PAC Channels and Their Roles in Cell Volume Dysregulation and Acidotoxic Cell Death. Front. Cel Dev. Biol. 9, 702317. doi:10.3389/ fcell.2021.702317

Okada, Y., Shimizu, T., Maeno, E., Tanabe, S., Wang, X., and Takahashi, N. (2006). Volume-sensitive Chloride Channels Involved in Apoptotic Volume Decrease and Cell Death. J. Membr. Biol 209, 21-29. doi:10.1007/s00232-005-0836-6

Pauli, C., Grogan, S. P., Patil, S., Otsuki, S., Hasegawa, A., Koziol, J., et al. (2011). Macroscopic and Histopathologic Analysis of Human Knee Menisci in Aging and Osteoarthritis. Osteoarthritis and Cartilage 19, 1132-1141. doi:10.1016/ j.joca.2011.05.008

Pedersen, S. F., Klausen, T. K., and Nilius, B. (2015). The Identification of a Volume-Regulated Anion Channel: an Amazing Odyssey. Acta Physiol. 213, 868-881. doi:10.1111/apha.12450

Pedersen, S. F., Okada, Y., and Nilius, B. (2016). Biophysics and Physiology of the Volume-Regulated Anion Channel (VRAC)/Volume-Sensitive Outwardly Rectifying Anion Channel (VSOR). Pflugers Arch. - Eur. J. Physiol. 468, 371-383. doi:10.1007/s00424-015-1781-6

Pereverzev, A., Komarova, S. V., Korčok, J., Armstrong, S., Tremblay, G. B., Dixon, S. J., et al. (2008). Extracellular Acidification Enhances Osteoclast Survival through an NFAT-independent, Protein Kinase C-dependent Pathway. Bone 42, 150-161. doi:10.1016/j.bone.2007.08.044 
Pethö, Z., Najder, K., Carvalho, T., Mcmorrow, R., Todesca, L. M., Rugi, M., et al. (2020). pH-Channeling in Cancer: How pH-Dependence of Cation Channels Shapes Cancer Pathophysiology. Cancers 12, 2484. doi:10.3390/ cancers 12092484

Planells-Cases, R., Lutter, D., Guyader, C., Gerhards, N. M., Ullrich, F., Elger, D. A., et al. (2015). Subunit Composition of VRAC Channels Determines Substrate Specificity and Cellular Resistance to P T-based Anti-cancer Drugs. EMBO J. 34, 2993-3008. doi:10.15252/embj.201592409

Porcelli, A. M., Ghelli, A., Zanna, C., Valente, P., Ferroni, S., and Rugolo, M. (2004). Apoptosis Induced by Staurosporine in ECV304 Cells Requires Cell Shrinkage and Upregulation of $\mathrm{Cl}-$ Conductance. Cel Death Differ 11, 655-662. doi:10.1038/sj.cdd.4401396

Poulsen, K. A., Andersen, E. C., Hansen, C. F., Klausen, T. K., Hougaard, C., Lambert, I. H., et al. (2010). Deregulation of Apoptotic Volume Decrease and Ionic Movements in Multidrug-Resistant Tumor Cells: Role of Chloride Channels. Am. J. Physiology-Cell Physiol. 298, C14-C25. doi:10.1152/ ajpcell.00654.2008

Puppulin, L., Hosogi, S., Sun, H., Matsuo, K., Inui, T., Kumamoto, Y., et al. (2018). Bioconjugation Strategy for Cell Surface Labelling with Gold Nanostructures Designed for Highly Localized pH Measurement. Nat. Commun. 9, 5278. doi:10.1038/s41467-018-07726-5

Rasola, A., Far, D. F., Hofman, P., and Rossi, B. (1999). Lack of Internucleosomal DNA Fragmentation Is Related to C1 - Efflux Impairment in Hematopoietic Cell Apoptosis. FASEB j. 13, 1711-1723. doi:10.1096/fasebj.13.13.1711

Sato-Numata, K., Numata, T., and Okada, Y. (2014). Temperature Sensitivity of Acid-Sensitive Outwardly Rectifying (ASOR) Anion Channels in Cortical Neurons Is Involved in Hypothermic Neuroprotection against Acidotoxic Necrosis. Channels 8, 278-283. doi:10.4161/chan.27748

Schwab, A., Fabian, A., Hanley, P. J., and Stock, C. (2012). Role of Ion Channels and Transporters in Cell Migration. Physiol. Rev. 92, 1865-1913. doi:10.1152/ physrev.00018.2011

Sharma, M., Sahu, K., Dube, A., and Gupta, P. K. (2005). Extracellular pH Influences the Mode of Cell Death in Human colon Adenocarcinoma Cells Subjected to Photodynamic Treatment with Chlorin P6. J. Photochem. Photobiol. B: Biol. 81, 107-113. doi:10.1016/j.jphotobiol.2005.07.001

Shimizu, T., Numata, T., and Okada, Y. (2004). A Role of Reactive Oxygen Species in Apoptotic Activation of Volume-Sensitive Cl- Channel. Proc. Natl. Acad. Sci. 101, 6770-6773. doi:10.1073/pnas.0401604101

Smith, M.-L., Von Hanwehr, R., and Siesjö, B. K. (1986). Changes in Extra- and Intracellular $\mathrm{pH}$ in the Brain during and Following Ischemia in Hyperglycemic and in Moderately Hypoglycemic Rats. J. Cereb. Blood Flow Metab. 6, 574-583. doi:10.1038/jcbfm.1986.104

Terminella, C., Tollefson, K., Kroczynski, J., Pelli, J., and Cutaia, M. (2002). Inhibition of Apoptosis in Pulmonary Endothelial Cells by Altered $\mathrm{pH}$, Mitochondrial Function, and ATP Supply. Am. J. Physiology-Lung Cell Mol. Physiol. 283, L1291-L1302. doi:10.1152/ajplung.00246.2001

Thatte, H. S., Rhee, J.-H., Zagarins, S. E., Treanor, P. R., Birjiniuk, V., Crittenden, M. D., et al. (2004). Acidosis-induced Apoptosis in Human and Porcine Heart. Ann. Thorac. Surg. 77, 1376-1383. doi:10.1016/ j.athoracsur.2003.07.047

Voets, T., Droogmans, G., and Nilius, B. (1997). Modulation of Voltage-dependent Properties of a Swelling-Activated Cl- Current. J. Gen. Physiol. 110, 313-325. doi:10.1085/jgp.110.3.313

Wang, H.-Y., Shimizu, T., Numata, T., and Okada, Y. (2007). Role of AcidSensitive Outwardly Rectifying Anion Channels in Acidosis-Induced Cell Death in Human Epithelial Cells. Pflugers Arch. - Eur. J. Physiol. 454, 223-233. doi:10.1007/s00424-006-0193-Z

Wang, L., Shen, M., Guo, X., Wang, B., Xia, Y., Wang, N., et al. (2017). Volumesensitive Outwardly Rectifying Chloride Channel Blockers Protect against High Glucose-Induced Apoptosis of Cardiomyocytes via Autophagy Activation. Sci. Rep. 7, 44265. doi:10.1038/srep44265

Wanitchakool, P., Ousingsawat, J., Sirianant, L., Macaulay, N., Schreiber, R., and Kunzelmann, K. (2016). Cl- Channels in Apoptosis. Eur. Biophys. J. 45, 599-610. doi:10.1007/s00249-016-1140-3

Wei, L., Xiao, A. Y., Jin, C., Yang, A., Lu, Z. Y., and Yu, S. P. (2004). Effects of Chloride and Potassium Channel Blockers on Apoptotic Cell Shrinkage and Apoptosis in Cortical Neurons. Pflugers Archiv Eur. J. Physiol. 448, 325-334. doi:10.1007/s00424-004-1277-2

Winklmayr, M., Gaisberger, M., Kittl, M., Fuchs, J., Ritter, M., and Jakab, M. (2019). Dose-Dependent Cannabidiol-Induced Elevation of Intracellular Calcium and Apoptosis in Human Articular Chondrocytes. J. Orthop. Res. 37, 2540-2549. doi:10.1002/jor.24430

Xu, L., Glassford, A. J. M., Giaccia, A. J., and Giffard, R. G. (1998). Acidosis Reduces Neuronal Apoptosis. Neuroreport 9, 875-879. doi:10.1097/00001756199803300-00021

Yurinskaya, V., Aksenov, N., Moshkov, A., Goryachaya, T., Shemery, A., and Vereninov, A. (2020). Flow Fluorometry Quantification of Anion Channel VRAC Subunit LRRC8A at the Membrane of Living U937 Cells. Channels 14, 45-52. doi:10.1080/19336950.2020.1730535

Conflict of Interest: The authors declare that the research was conducted in the absence of any commercial or financial relationships that could be construed as a potential conflict of interest.

Publisher's Note: All claims expressed in this article are solely those of the authors and do not necessarily represent those of their affiliated organizations, or those of the publisher, the editors, and the reviewers. Any product that may be evaluated in this article, or claim that may be made by its manufacturer, is not guaranteed or endorsed by the publisher.

Copyright $\odot 2022$ Kittl, Winklmayr, Preishuber-Pflügl, Strobl, Gaisberger, Ritter and Jakab. This is an open-access article distributed under the terms of the Creative Commons Attribution License (CC BY). The use, distribution or reproduction in other forums is permitted, provided the original author(s) and the copyright owner(s) are credited and that the original publication in this journal is cited, in accordance with accepted academic practice. No use, distribution or reproduction is permitted which does not comply with these terms. 